\title{
17. CUMULUS AND POSTCUMULUS CRYSTALLIZATION IN THE OCEANIC CRUST: MAJOR- AND TRACE-ELEMENT GEOCHEMISTRY OF LEG 153 GABBROIC ROCKS ${ }^{1}$
}

\author{
Kent Ross ${ }^{2}$ and Don Elthon ${ }^{2}$
}

\begin{abstract}
Gabbroic rocks drilled at Sites 923 and 921 are cumulate rocks that crystallized from at least two distinct parental magmas. One parental magma was geochemically similar to basalts erupted near the Kane Fracture Zone. The second parental magma was substantially more depleted in incompatible trace elements. Primitive gabbros at Site 923 and 921 have abundant poikilitic clinopyroxene more magnesian ( $\mathrm{Mg} \#$ 88-84) than should crystallize from most mid-ocean ridge basalts (MORBs) at low pressure. This observation suggests that the gabbros drilled during Leg 153 could have formed at elevated pressure (2-5 kbar) or that they could have formed at low pressure from melts with compositions unlike erupted MORBs. Mass-balance modeling of incompatible trace-element abundances in gabbroic whole rocks suggests that these rocks are adcumulate to orthocumulate, with contents of trapped liquid that vary from near zero to about $30 \%$. Electron probe and ion probe data show enrichments of incompatible trace elements in portions of clinopyroxene grains that are attributed to postcumulus crystal growth from or interaction with evolving intercumulus melts. Trace-element-enriched zones in clinopyroxene commonly show little or no change in major-element compositions. The zirconium-bearing phase baddeleyite has been observed in 11 samples of the 55 gabbros examined in this study. Its occurrence in these rocks is anomalous, because it is expected that silica-saturated magmas will ultimately crystallize zircon $\left(\mathrm{ZrSiO}_{4}\right)$ at extreme degrees of fractionation, and not baddeleyite. The origin of baddeleyite in these rocks is enigmatic. Hornblende, apatite, and ilmenite are also common accessory phases in these rocks, occurring in samples with refractory mineral compositions. The presence of these phases suggests extensive crystallization of trapped intercumulus liquid, and yet extreme major-element zoning of plagioclase and mafic phases is not observed in rocks with late-stage phases.
\end{abstract}

\section{INTRODUCTION}

Leg 153 of the Ocean Drilling Program (ODP) recovered cores of gabbroic rock at Sites 921 through 924 by drilling directly into gabbroic outcrops exposed along the western wall of the median valley of the Mid-Atlantic Ridge south of the Kane Fracture Zone (MARK). Deep-seated plutonic rocks have been exposed on the seafloor because of extension along a large, east-dipping, detachment structure. Detailed studies of mineral and rock compositions of suites of gabbroic rocks from Sites 921 and 923 have been undertaken to improve our understanding of the formation of the plutonic section of the oceanic crust and of the evolution of mid-ocean ridge basalts. Studies of gabbroic rocks from the oceanic crust are important because processes that are inferred to influence the compositions of lavas erupted at spreading centers, such as crystal fractionation, crystal accumulation, in situ fractionation (Langmuir, 1989), and magma mixing, should be discernible in the gabbroic plutonic rocks that make up the foundations of the oceanic crust, so that models of mid-ocean ridge basalt (MORB) evolution can be tested by studying the plutonic section.

In this paper, the term cumulate is used to refer to rocks that are comprised of minerals that were separated, with varying degrees of efficiency, from the magmas from which they crystallized. The process of cumulate formation results in plutonic rocks whose compositions are very different from those of their parental magmas, because the rocks consist largely of mixtures of cumulus phases. The separation of crystals from magma can be accomplished by crystal settling, or by crystallization along the walls and floor of magma reservoirs, and the use of the term cumulate in this paper does not imply that crystal settling is the means by which the rocks investigated in this

'Karson, J.A., Cannat, M., Miller, D.J., and Elthon, D. (Eds,), 1997. Proc. ODP, Sci. Results, 153: College Station, TX (Ocean Drilling Program).

${ }^{2}$ Department of Chemistry, and the Texas Center for Superconductivity, University of Houston, Houston, TX 77204-5641, U.S.A. DKROSS@UH.EDU study were formed. Cumulate rocks have been distinguished on the basis of the quantity of trapped melt that they contain. Rocks that contain greater than $25 \%$ trapped melt are referred to as orthocumulates, those that contain from $7 \%$ to $25 \%$ trapped melt are mesocumulates, and those that contain less than $7 \%$ are adcumulates (for discussions of cumulus terminology and processes, see Wager et al., 1960; and Irvine, 1982). The pore spaces between cumulus mineral grains can be filled in various ways. Crystal growth from trapped or evolving interstitial liquid during cooling results in zoning of mineral phases. Trapping of interstitial melt leads to enrichment of the bulk rock in trace elements that are incompatible in the cumulus mineral grains. Overgrowth of rims similar in composition to the original cumulus grains is known as adcumulus growth. Heteradcumulates are rocks in which postcumulus crystal growth formed phases other than the original cumulus phases, and these phases grew from a primitive melt that was not evolving, so that heteradcumulus grains are not zoned and have primitive compositions. The amount of trapped liquid present in cumulate rocks may be estimated using abundances of strongly incompatible trace elements, although some assumption about the composition of the trapped liquid must be made.

Gabbroic rocks recovered from the MARK area are of cumulate origin, based on bulk-rock compositions, most of which are substantially depleted in incompatible trace elements relative to spatially associated erupted lavas and to their parental melts, whose compositions have been inferred from clinopyroxene compositions in the gabbros. The existence of these cumulate gabbros constitute prima facie evidence for the operation of crystal fractionation with effective separation of melt from crystals. Gabbroic rocks drilled during Leg 153 exhibit various features that are typical of cumulate rocks from basic layered intrusions, such as grain-size layering, modal layering, phase layering, and formation of poikilitic mineral grains (Cannat, Karson, Miller, et al., 1995). The physicochemical conditions prevailing during gabbroic rock crystallization at the MARK area resulted in the development of classic textural features typical of cumulate rock formation. 


\section{ANALYTICAL METHODS}

Major- and minor-element mineral compositions were determined by electron microprobe analysis. These data were collected using the JEOL JXA-8600 Superprobe at the University of Houston. Polished thin sections were prepared from 55 gabbroic rock samples from Sites 921, 922, and 923. X-ray intensity data were reduced using an on-line NORAN ZAF routine. The electron probe was operated using an accelerating voltage of $15 \mathrm{kV}$ and a beam current of $30 \mathrm{nA}$. Six to nine spots on several grains for each major constituent phase were analyzed. Pyroxene analyses were obtained using a defocused beam with a diameter of $25 \mu \mathrm{m}$, to attempt to determine magmatic (pre-exsolution) pyroxene compositions. Exsolution lamellae of lowcalcium pyroxene in host augites are ubiquitous. Plagioclase was analyzed using a $10-\mu \mathrm{m}$ defocused beam to prevent sodium migration during exposure to the electron beam. A $10-\mu \mathrm{m}$ spot diameter was also used for analysis of apatites. Oxides and olivine were analyzed using $1-\mu \mathrm{m}$ spot diameter. Elements were calibrated using natural and synthetic mineral and glass standards. Counting times were generally set at $100 \mathrm{~s}$ for the peak, with 50 -s counting times on background positions on either side of the peak.

Instrumental neutron activation analysis (INAA) of whole-rock powders and mineral separates from selected samples have been obtained using the laboratory at the NASA Johnson Space Center. Gamma-ray spectra were processed using the TEABAGS program (Lindstrom and Korotev, 1982). Whole-rock powders were prepared by choosing a sawn piece of sample adjacent to the material from which mineral separates were obtained. The sample was jawcrushed using hardened steel plates and powdered in a SPEX mill using hardened steel container and balls. Plagioclase and clinopyroxene mineral separates were obtained by jawcrushing ultrasonically cleaned pieces of fresh sample, sieving the resulting crumbled rock, recovering the 250 - to $500-\mu \mathrm{m}$-sized fraction, magnetically separating initial plagioclase, clinopyroxene, and olivine fractions, and finally careful handpicking under a stereoscopic microscope. Separates of 50-100 mg were obtained by this procedure and this material was then ultrasonically cleaned in 1-N HCL for 5-10 min. The resulting mineral separates were $>99 \%$ pure.

Rare-earth element (REE) and trace-element compositions of clinopyroxene were obtained by secondary ion mass spectrometry at the
Woods Hole Oceanographic Institution in Dr. N. Shimizu's laboratory. Round, 1-in-diameter, thin-section mounts of selected gabbroic rocks were prepared for ion probe studies, so that clinopyroxene grains could be analyzed in situ to permit evaluation of trace-element zoning. Energy filtering suppressed molecular interferences (Shimi$\mathrm{zu}$ and Hart, 1982). The ion probe excavates a pit that is about 20-25 $\mu \mathrm{m}$ in diameter and about $25 \mu \mathrm{m}$ deep. Given the scale of exsolution in clinopyroxene common in these rocks, with exsolution lamellae that are $1-3 \mu \mathrm{m}$ wide of orthopyroxene in clinopyroxene hosts, it is unlikely that exsolution phenomena produce the scatter in ion probe data observed. The instrument collects ion intensity ratios repeatedly, over a period of about $25 \mathrm{~min}$ during REE analyses and $20 \mathrm{~min}$ for other trace-element analyses. The data presented are average results from these repeated measurements.

\section{PETROGRAPHY AND MINERALOGY}

Samples selected for this study consist of some combination of plagioclase, clinopyroxene, orthopyroxene, olivine, and/or oxide minerals (ilmenite and/or magnetite) as major or minor mineralogic constituents. Trace constituents include apatite, brown pleochroic amphibole, zirconia, and sulfide minerals as likely or possible primary disseminated trace minerals. These samples also include various secondary alteration phases, generally in minor abundances. Talc, magnetite, chlorite, and actinolite are among the most common alteration phases. The samples used were chosen based on their freshness because primary geochemical and mineralogic features are the focus of this study.

Calculated primary modes, along with observed trace minerals and rock names, for the Site 923 suite of samples are presented in Table 1 . Trace minerals were determined by transmitted light microscopy, reflected light microscopy, backscattered electron imaging, and energy dispersive X-ray analysis. The modal abundances of olivine, clinopyroxene, plagioclase, orthopyroxene, and oxide minerals, when present, were calculated on the basis of whole-rock and mineral abundances of $\mathrm{FeO}, \mathrm{CaO}, \mathrm{Na}_{2} \mathrm{O}, \mathrm{Cr}$, and $\mathrm{Ni}$. Modal data were derived from bulk-rock chemical data to permit the use of these modes in modeling incompatible trace-element abundances in whole-rock samples. The use of modes derived directly from bulk-rock chemical

Table 1. Calculated modal data for Hole 923A gabbros.

\begin{tabular}{|c|c|c|c|c|c|c|c|}
\hline $\begin{array}{l}\text { Core, section, } \\
\text { interval }(\mathrm{cm})\end{array}$ & Olivine & Clinopyroxene & Plagioclase & Orthopyroxene & Oxides & Others & Rock type \\
\hline \multicolumn{8}{|l|}{$153-923 \mathrm{~A}-$} \\
\hline $3 \mathrm{R}-1,138-141$ & 8.0 & 45.0 & 47.0 & $\operatorname{Tr}$ & $\mathrm{Tr}$ & hbl, sul & Olivine gabbro \\
\hline $4 \mathrm{R}-1,35-37$ & & 24,0 & 45.5 & 23.5 & 7 & bad, ap, hbl & Oxide gabbronorite \\
\hline $4 \mathrm{R}-1,127-131$ & 14.5 & 28.5 & 57.0 & & $\operatorname{Tr}$ & hbl, sul, ap & Olivine gabbro \\
\hline $5 R-1,58-63$ & 11.0 & 24.5 & 64.5 & & $\mathrm{Tr}$ & hbl, sul & Poikilitic olivine gabbro \\
\hline $6 \mathrm{R}-2,18-23$ & 12.5 & 41.0 & 46.5 & & $\mathrm{Tr}$ & hbl, sul & Olivine gabbro \\
\hline $7 R-2,34-40$ & 11.0 & 5.0 & 82.0 & & 2 & ap, hbl, sul & Poikilitic olivine gabbro \\
\hline $8 R-1,61-65$ & 13.5 & 31.5 & 55.0 & & $\operatorname{Tr}$ & ap, hbl, sul & Olivine gabbro \\
\hline $8 R-2,96-100$ & 11.5 & 33.0 & 55.5 & $\mathrm{Tr}$ & $\mathrm{Tr}$ & hbl, sul & Olivine gabbro \\
\hline $9 \mathrm{R}-1,135-141$ & 8.5 & 33.0 & 58.5 & 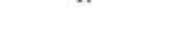 & $\operatorname{Tr}$ & hbl, sul & Olivine gabbro \\
\hline $9 \mathrm{R}-3,10-15$ & 8.5 & 34.0 & 57.5 & & $\mathrm{Tr}$ & hbl, sul & Olivine gabbro \\
\hline 10R-2, 122-127 & 12.0 & 23.0 & 65.0 & $\operatorname{Tr}$ & $\mathrm{Tr}$ & hbl, sul & Olivine gabbro \\
\hline $15 \mathrm{R}-2,114-118$ & 17.0 & 12.0 & 71.0 & & $\mathrm{Tr}$ & hbl, sul & Poikilitic olivine gabbro \\
\hline $15 R-3,21-25$ & 17.0 & 13.7 & 69.3 & & $\operatorname{Tr}$ & ap, hbl, sul & Poikilitic olivine gabbro \\
\hline $16 \mathrm{R}-3,5-9$ & 33.0 & 7.0 & 60.0 & & $\operatorname{Tr}$ & bad, ap, hbl, sul & Poikilitic olivine gabbro \\
\hline $16 \mathrm{R}-4,17-21$ & 20.0 & 20.0 & 60.0 & & $\mathrm{Tr}$ & bad, ap, hbl, sul & Poikilitic olivine gabbro \\
\hline
\end{tabular}

Notes: Phases listed in the "Others" column generally make up $<1 \%$ of the mode. Modes are given in wt $\%$ (calculated by mass balancing abundances of $\mathrm{CaO}, \mathrm{FeO}, \mathrm{Na} \mathrm{O}_{2} \mathrm{O}, \mathrm{Cr}$, and $\mathrm{Ni}$ ). Trace phases were determined petrographically, by backscattered electron imaging, and by energy dispersive spectrometer (EDS) observations. Phase abbreviations are defined as follows: bad = baddeleyite $\left(\mathrm{ZrO}_{2}\right), \mathrm{hbl}=$ brown amphibole, sul = sulfide minerals, and ap = apatite. "Tr" signifies that the phase is present at trace abundance levels $(<<1 \%)$. 
data was deemed more appropriate than the use of point-counted modes on thin sections because the latter might not be representative of the aliquot from which INAA data was collected.

Modal abundances were calculated by mass balancing whole-rock contents of $\mathrm{FeO}, \mathrm{CaO}, \mathrm{Na}_{2} \mathrm{O}, \mathrm{Cr}$, and $\mathrm{Ni}$. The abundance of these elements were determined in whole rocks by INAA, and in mineral phases by electron probe or INAA. Modal abundances were calculated interactively in a spreadsheet program, and the phases included in the mass-balance calculations were constrained from petrographic observations. The amount of plagioclase in each sample is tightly constrained by the bulk-rock $\mathrm{Na}_{2} \mathrm{O}$, because plagioclase is the dominant reservoir of sodium in these rocks. FeO in the bulk-rock constrains the relative proportions of mafic phases (clinopyroxene and olivine are the dominant iron-bearing phases in all rocks except those few that have abundant orthopyroxene or iron-titanium oxides). $\mathrm{Na}_{2} \mathrm{O}$ and $\mathrm{FeO}$ are measured with high precision by INAA (typical errors at the $2 \sigma$ level are $1 \%-2 \%$ relative for $\mathrm{FeO}$ and $\mathrm{Na}_{2} \mathrm{O}$ ). $\mathrm{CaO}$ has relatively high errors measured by INAA ( $5 \%-10 \%$ relative) and $\mathrm{Cr}$ and $\mathrm{Ni}$ can also be present in oxides and sulfides respectively, so that mass-balance calculations were performed with misfits minimized for $\mathrm{Na}_{2} \mathrm{O}$ and $\mathrm{FeO}$. Errors on modal data are estimated to be less than $3 \%$ relative for samples with only olivine, plagioclase, and clinopyroxene as major constituent phases (all but two samples). In trapped liquid modeling discussed in a later section of this paper, calculated modes are used to model the trace-element abundances in these rocks. Inferred amounts of trapped melt in these samples are rather insensitive to errors in the modes, because melt is strongly enriched in incompatible trace elements relative to the crystalline phases.

The Site 923 rocks are dominantly olivine gabbros, with minor troctolitic gabbros and oxide gabbronorites. Olivine gabbros in this suite have been subdivided on the basis of the textures of clinopyroxene in these samples. In "olivine gabbro," clinopyroxene is a cumulus phase with numerous subhedral grains that rarely enclose other mineral phases. In "poikilitic olivine gabbro" clinopyroxene encloses plagioclase grains, or is interstitial to euhedral or subhedral plagioclase. This texture is commonly thought to suggest that clinopyroxene grew within pore spaces whose shape was defined by surrounding plagioclase grains. In hand specimen and in thin section, poikilitic clinopyroxene grains can be recognized because physically separated grains are in optical continuity. In this suite, poikilitic clinopyroxene commonly grew with large inclusion-free cores (2-4 $\mathrm{cm}$ ) and margins intergrown with surrounding euhedral to subhedral cumulus plagioclase grains. Primary clinopyroxene textures in poikilitic rocks are illustrated in Cannat, Karson, Miller, et al. (1995, fig. 4, p. 183 ; fig. 14 , p. 188 ; figs.18A, B, p. 230; fig. 20 A, p. 232). Reddish brown rims on poikilitic clinopyroxene are low in chromium and enriched in $\mathrm{TiO}_{2}$. The cores are magnesian and chrome rich. Poikilitic grain textures have been viewed as evidence for melt trapping or postcumulus crystal growth because the inclusion of primary cumulus phases in poikilitic grains indicates that their growth occurred after the formation of cumulus phases. Haskin and Salpas (1992) have shown that poikilitic and interstitial mafic grains in Stillwater anorthosites have geochemical characteristics, such as refractory major-element compositions and high abundances of compatible elements, similar to cumulus material. In the oceanic cumulates that are the focus of the present study, it will be shown that this observation holds; phases with postcumulus textures geochemically are like cumulus material, but have rims or zones that are enriched in incompatible trace elements.

\section{ELECTRON MICROPROBE RESULTS}

Mean olivine compositions are presented in Table 2. At Site 923, olivine ranges in composition from $\mathrm{Fo}_{84.2}$ to $\mathrm{Fo}_{64.7}$ (forsterite [Fo] is the molar ratio $100 \times \mathrm{Mg} /[\mathrm{Mg}+\mathrm{Fe}])$ with $\mathrm{NiO}$ contents that vary from 0.21 to $0.05 \mathrm{wt} \%$. Olivine at Sites 921 and 922 have composi- tions ranging from $\mathrm{Fo}_{84}$ to $\mathrm{Fo}_{59}$. Crystallization modeling (using the program MIXNFRAC; Nielsen, 1988) indicates that about 50\% perfect fractional crystallization of a primitive Kane basaltic liquid (sample 649B 1 007F; data from Bryan et al., 1993) is required to produce olivine compositions with this range of forsterite contents. Mean plagioclase compositions are presented in Table 3. Mean anorthite $(\mathrm{An})$ contents in plagioclase (molar ratio $\mathrm{Ca} /[\mathrm{Ca}+\mathrm{Na}+\mathrm{K}]$ ) range from $\mathrm{An}_{74}$ to $\mathrm{An}_{44}$ at Site 923, from $\mathrm{An}_{73}$ to $\mathrm{An}_{40}$ at Site 921, and from $\mathrm{An}_{77}$ to $\mathrm{An}_{48}$ at Site 922. Fractional crystallization modeling suggests that approximately $50 \%$ fractional crystallization is required to produce the observed range of anorthite values at Site 923. The estimated amount of crystallization needed to produce the full range of mineral compositions in these rocks is based on the assumption of a single parental magma. In a later section of this paper, it will be shown that two distinct parental magmas were involved in the formation of this suite. The degree of crystal fractionation of these magmas will be discussed further in the section that follows.

One notable feature of plagioclase compositions in these rocks is the substantial variability within individual samples. Tables 2 and 3 show standard deviations for forsterite contents in olivine and anorthite contents in plagioclase. It is apparent from the standard deviations that plagioclase compositions are more variable than olivine compositions within most samples. Analytical uncertainties based on counting statistics on forsterite and anorthite ratios are $0.5(2 \sigma)$ so those samples with standard deviations of Fo and An that exceed 1 clearly do not have uniform mineral compositions. In most samples, olivine compositions are essentially uniform, but those of plagioclase are not. Variable plagioclase compositions could result from postcumulus crystallization from intercumulus melts, or, in some cases, the plagioclase grains deposited at the cumulus stage might have been variable.

The wide range of plagioclase compositions in individual samples suggests that postcumulus crystal growth during cooling of the crystal mush has deposited plagioclase from a range of intercumulus melt compositions. In two samples with oxide-rich veins (Samples 153921D-5R-2, 0-4 cm, and 922A-3R-1, 23-27 cm) plagioclase analyses within the oxide veins or proximal to oxide concentrations have mean An values that are 19 and 29 units lower in the vein, relative to plagioclase distal from the oxide concentrations with no overlap in vein and host plagioclase compositions. The range of plagioclase compositions in most samples shows that the intercumulus liquid did not evolve to the extreme degrees of crystallization required to crystallize Fe-Ti oxide minerals, apatites, or zirconium-bearing late-stage phases, yet these late-stage phases are found in many rocks. Ilmenite occurs as a disseminated accessory phase in every cumulate gabbro, even the most primitive samples. Accessory ilmenite and apatite are usually observed in interstitial spaces between cumulus grains, but they have also been observed enclosed in magnesian mafic phases.

Mean forsterite in olivine is plotted vs. mean anorthite in plagioclase in Figure 1. The data define a broad trend of decreasing forsterite with decreasing anorthite. The scatter in this trend could reflect either variable parental magmas or varying extents of postcumulus crystal growth from evolving intercumulus liquid. Fo in olivine is plotted vs. $\mathrm{NiO}$ in olivine in Figure 2. This plot shows a fractionation sequence, with a compositional gap between the residual mantle samples drilled during Leg 153 and the most primitive gabbroic samples that indicates that the most primitive portion of the cumulate sequence was not sampled by drilling in the gabbroic rocks. These olivines are the products of fractional crystallization from magmas with $\mathrm{Mg} \#$ ranging from approximately 65 to 40 .

$\mathrm{Mg}$ \# in clinopyroxene $\left(100 \times \mathrm{Mg} /\left[\mathrm{Mg}+\mathrm{Fe}^{\mathrm{t}}\right]\right)$ is plotted vs. anorthite in plagioclase in the Leg 153 gabbroic rocks in Figure 3. Also shown are fields for other oceanic cumulate rocks. The data define a trend of decreasing An with decreasing $\mathrm{Mg \#}$. The trend of these data is similar to that from Leg 118 (Hébert et al., 1991) and the Mid-Cayman Rise (Elthon, 1987), indicating that the Leg 153 samples crystallized from relatively high-Na MORB. Clinopyroxene mineral com- 
Table 2. Average olivine compositions in Leg 153 gabbros.

\begin{tabular}{|c|c|c|c|c|c|c|c|c|c|c|}
\hline $\begin{array}{l}\text { Core, section, } \\
\text { interval }(\mathrm{cm})\end{array}$ & $n$ & $\mathrm{SiO}_{2}$ & $\mathrm{FeO}$ & $\mathrm{MnO}$ & $\mathrm{NiO}$ & $\mathrm{MgO}$ & $\mathrm{CaO}$ & Total & Fo & 1 s.d. \\
\hline \multicolumn{11}{|l|}{$153-923 \mathrm{~A}-$} \\
\hline $3 \mathrm{R}-1,138-141$ & 7 & 37.86 & 26.27 & 0.42 & 0.08 & 35.80 & 0.04 & 100.47 & 70. & \pm 0.5 \\
\hline $4 \mathrm{R}-1,127-131$ & 7 & 36.87 & 30.67 & 0.48 & 0.05 & 31.57 & 0.05 & 99.69 & 64.7 & \pm 0.4 \\
\hline $5 \mathrm{R}-1,58-63$ & 7 & 37.97 & 26.94 & 0.41 & 0.07 & 35.65 & 0.05 & 101.09 & 70.2 & \pm 0.2 \\
\hline $5 \mathrm{R}-2,0-5$ & 6 & 37.28 & 27.54 & 0.44 & 0.07 & 34.51 & 0.04 & 99.88 & 69.1 & \pm 0.3 \\
\hline $5 \mathrm{R}-3,0-6$ & 7 & 37.68 & 28.79 & 0.45 & 0.06 & 34.24 & 0.04 & 101.26 & 67.9 & \pm 0.2 \\
\hline $6 \mathrm{R}-2,18-23$ & 7 & 37.55 & 25.30 & 0.40 & 0.08 & 36.56 & 0.04 & 99.93 & 72.0 & \pm 0.2 \\
\hline $7 \mathrm{R}-2,34-40$ & 8 & 38.61 & 22.75 & 0.37 & 0.15 & 38.91 & 0.05 & 100.84 & 75.3 & \pm 0.3 \\
\hline $8 \mathrm{R}-1,61-65$ & 7 & 38.02 & 24.94 & 0.40 & 0.09 & 36.35 & 0.05 & 99.85 & 72.2 & \pm 0.7 \\
\hline $8 \mathrm{R}-2,96-100$ & 7 & 37.26 & 26.03 & 0.40 & 0.08 & 35.89 & 0.04 & 99.70 & 71.1 & \pm 0.3 \\
\hline $9 \mathrm{R}-1,135-141$ & 7 & 38.37 & 24.27 & 0.37 & 0.08 & 37.62 & 0.06 & 100.77 & 73.4 & \pm 0.3 \\
\hline $9 \mathrm{R}-3,10-15$ & 7 & 37.53 & 27.55 & 0.40 & 0.06 & 34.42 & 0.04 & 100.00 & 69.0 & \pm 0.2 \\
\hline $10 \mathrm{R}-2,122-127$ & 7 & 37.85 & 25.55 & 0.39 & 0.07 & 36.00 & 0.04 & 99.90 & 71.5 & \pm 0.4 \\
\hline $11 \mathrm{R}-2,129-135$ & 7 & 39.87 & 15.00 & 0.24 & 0.21 & 44.80 & 0.06 & 100.18 & 84.2 & \pm 0.6 \\
\hline $12 \mathrm{R}-1,24-28$ & 8 & 38.73 & 19.59 & 0.31 & 0.15 & 41.07 & 0.05 & 99.90 & 78.9 & \pm 1.0 \\
\hline $12 \mathrm{R}-1,115-120$ & 6 & 38.79 & 17.70 & 0.29 & 0.17 & 43.11 & 0.06 & 100.12 & 81.9 & \pm 0.1 \\
\hline $13 R-1,65-69$ & 8 & 37.64 & 26.46 & 0.40 & 0.08 & 36.17 & 0.05 & 100.80 & 70.9 & \pm 0.2 \\
\hline $14 \mathrm{R}-1,36-40$ & 6 & 38.58 & 23.40 & 0.39 & 0.12 & 38.48 & 0.05 & 101.02 & 74.6 & \pm 0.3 \\
\hline $15 \mathrm{R}-2,114-118$ & 7 & 38.97 & 19.53 & 0.32 & 0.14 & 41.21 & 0.05 & 100.22 & 79.0 & \pm 0.2 \\
\hline $15 R-3,21-25$ & 7 & 38.73 & 19.66 & 0.31 & 0.13 & 41.02 & 0.05 & 99.90 & 78.8 & \pm 0.3 \\
\hline $16 \mathrm{R}-3,5-9$ & 7 & 39.26 & 18.75 & 0.32 & 0.14 & 41.86 & 0.06 & 100.39 & $\begin{array}{l}79.6 \\
\end{array}$ & \pm 0.6 \\
\hline $16 R-4,17-21$ & 7 & 38.77 & 20.85 & 0.35 & 0.13 & 39.86 & 0.12 & 100.08 & 77.3 & \pm 0.6 \\
\hline \multicolumn{11}{|l|}{$\begin{array}{l}153-921 \mathrm{~A}- \\
2 \mathrm{R}-2 \mathrm{~A}-15\end{array}$} \\
\hline $2 \mathrm{R}-2,12-15$ & 7 & 36.78 & 32.27 & 0.52 & 0.04 & 30.90 & 0.06 & 100.57 & 63.1 & \pm 0.3 \\
\hline \multicolumn{11}{|l|}{ 153-921B- } \\
\hline $2 \mathrm{R}-1,120-124$ & 7 & 37.30 & 30.06 & 0.48 & 0.06 & 32.70 & 0.04 & 100.64 & 66.0 & \pm 0.4 \\
\hline $2 \mathrm{R}-2,89-93$ & 6 & 38.32 & 23.87 & 0.37 & 0.08 & 37.94 & 0.04 & 100.62 & 73.9 & \pm 0.6 \\
\hline $3 \mathrm{R}-1,144-147$ & 7 & 37.92 & 26.32 & 0.42 & 0.07 & 35.87 & 0.06 & 100.66 & 70.8 & \pm 0.3 \\
\hline $3 \mathrm{R}-2,71-75$ & 6 & 38.21 & 21.55 & 0.33 & 0.09 & 39.29 & 0.04 & 99.51 & 76.5 & \pm 0.4 \\
\hline $4 \mathrm{R}-1,52-57$ & 6 & 39.26 & 19.68 & 0.32 & 0.14 & 41.26 & 0.06 & 100.72 & 78.9 & \pm 0.8 \\
\hline $4 \mathrm{R}-2,25-30$ & 7 & 39.36 & 17.96 & 0.31 & 0.16 & 42.34 & 0.06 & 100.19 & 80.8 & \pm 0.3 \\
\hline $4 \mathrm{R}-2,122-126$ & 7 & 38.27 & 21.69 & 0.36 & 0.13 & 38.94 & 0.06 & 99.45 & 76.2 & \pm 0.7 \\
\hline $4 \mathrm{R}-3,90-96$ & 6 & 39.34 & 16.61 & 0.29 & 0.18 & 43.41 & 0.06 & 99.89 & 82.3 & \pm 0.4 \\
\hline $4 R-4,1-5$ & 7 & 39.40 & 16.66 & 0.28 & 0.19 & 43.18 & 0.05 & 99.76 & 82.2 & \pm 0.2 \\
\hline \multicolumn{11}{|l|}{$153-921 \mathrm{C}-$} \\
\hline $2 \mathrm{R}-2,70-75$ & 7 & 38.98 & 20.56 & 0.33 & 0.14 & 40.53 & 0.06 & 100.60 & 77.8 & \pm 0.4 \\
\hline $3 R-1,108-110$ & 8 & 37.53 & 24.67 & 0.40 & 0.12 & 36.65 & 0.05 & 99.42 & 72.6 & \pm 2.2 \\
\hline \multicolumn{11}{|l|}{ 153-921D- } \\
\hline $2 \mathrm{R}-1,13-18$ & 3 & 37.11 & 29.45 & 0.48 & 0.06 & 32.80 & 0.04 & 99.94 & 66.5 & \pm 0.1 \\
\hline $5 R-2,0-4$ & 7 & 37.07 & 29.16 & 0.55 & 0.07 & 33.19 & 0.06 & 100.10 & 67.0 & \pm 3.7 \\
\hline \multicolumn{11}{|l|}{ 153-921E. } \\
\hline $2 \mathrm{R}-2,8-12$ & 7 & 37.14 & 29.98 & 0.48 & 0.07 & 32.66 & 0.05 & 100.38 & 66.0 & \pm 1.3 \\
\hline $3 \mathrm{R}-1,19-24$ & 6 & 36.23 & 34.82 & 0.56 & 0.05 & 28.60 & 0.06 & 100.32 & 59.4 & \pm 0.3 \\
\hline $3 \mathrm{R}-1,81-85$ & 7 & 37.93 & 24.69 & 0.41 & 0.09 & 37.02 & 0.03 & 100.17 & 72.8 & \pm 0.5 \\
\hline $5 \mathrm{R}-2,19-24$ & 7 & 39.21 & 16.91 & 0.28 & 0.16 & 43.08 & 0.05 & 99.69 & 82.0 & \pm 0.2 \\
\hline $5 \mathrm{R}-3,23-26$ & 7 & 38.64 & 19.57 & 0.31 & 0.13 & 40.58 & 0.04 & 99.27 & 78.7 & \pm 0.7 \\
\hline $6 \mathrm{R}-1,101-106$ & 7 & 38.92 & 16.31 & 0.28 & 0.14 & 43.31 & 0.05 & 99.01 & 82.6 & \pm 0.5 \\
\hline $7 \mathrm{R}-2,12-17$ & 7 & 37.42 & 24.58 & 0.39 & 0.12 & 36.37 & 0.06 & 98.94 & 72.5 & \pm 2.4 \\
\hline $7 R-4,68-72$ & 7 & 39.04 & 19.80 & 0.33 & 0.13 & 40.43 & 0.07 & 99.80 & 78.5 & \pm 0.3 \\
\hline & & & \pm 1.7 \\
\hline \multicolumn{11}{|l|}{ 153-922B- } \\
\hline IW-1, 37-40 & 7 & 39.75 & 15.31 & 0.24 & 0.21 & 44.98 & 0.04 & 100.53 & 84.0 & \pm 0.3 \\
\hline $2 \mathrm{R}-1,17-2 \mathrm{l}$ & 7 & 39.31 & 16.66 & 0.29 & 0.17 & 43.72 & 0.06 & 100.21 & 82.4 & \pm 4.6 \\
\hline
\end{tabular}

Notes: All data are given in wt $\%$; " $n$ " is the number of analyses per sample; s.d. $=$ standard deviation. Fo $=$ forsterite $\left(100 \cdot \mathrm{Mg} /\left[\mathrm{Mg}+\mathrm{Fe}{ }^{\mathrm{t}}\right]\right.$, molar).

positions for Site 923 and 921 gabbroic rocks are shown in Table 4. $\mathrm{Mg} \#$ ranges from 88 to 70 in clinopyroxene. In samples with magnesian clinopyroxene, the texture of clinopyroxene grains is distinctive, with large, green, poikilitic clinopyroxene partly or entirely enclosing grains of plagioclase. These samples are classed as poikilitic olivine gabbros, and in some thin sections most or all clinopyroxene grains share one optical orientation. In some cases, poikilitic clinopyroxene grains have large (up to $6 \mathrm{~cm}$ ) cores that are free of inclusions, with margins that enclose plagioclase grains. It is not clear that this texture is entirely postcumulus. Rare nuclei of cumulus clinopyroxene could have continued to grow during the postcumulus stage, resulting in poikilitic margins. The origin of these magnesian poikilitic clinopyroxene grains is enigmatic, and not apparent from textures alone. Their textures are commonly thought to suggest that they are postcumulus, and yet they are the most primitive clinopyroxene grains in this suite of gabbros, with the highest $\mathrm{Mg \#}$ and $\mathrm{Cr}$ contents and the lowest incompatible-element abundances. These grains are heterogeneous with respect to $\mathrm{Cr}$ and $\mathrm{Ti}$ contents, but the variation in
$\mathrm{Mg} \#$ is usually restricted. We have obtained a complete data set for clinopyroxene at Site 923 , but have yet to complete analyses of clinopyroxene in samples from Site 921 . Ferric iron contents in clinopyroxene, calculated on the basis of stoichiometry and charge balance, generally make up less than $10 \%$ of the iron present in the clinopyroxene. Crystallization modeling (using the program of Nielsen, 1988 ) indicates that $50 \%$ perfect fractional crystallization is required to produce a change in $\mathrm{Mg} \#$ in clinopyroxene of 18 units. Nielsen's model run on a primitive Kane basalt (sample 649B $1007 \mathrm{~F}$; data from Bryan et al., 1993), however, produces an initial clinopyroxene with an $\mathrm{Mg} \#$ of 82 . As noted previously, in these rocks, clinopyroxene $\mathrm{Mg} \#$ extends to 88 . This problem will be discussed further in a later section.

The very primitive nature of magnesian clinopyroxene in poikilitic olivine gabbro is shown in Figure 4 by the high $\mathrm{Cr}_{2} \mathrm{O}_{3}$ contents in pyroxenes. Despite the compositional gap in $\mathrm{Mg} \#$ between clinopyroxene in residual mantle and in the early gabbros, the chrome contents of some clinopyroxene grains in primitive gabbros reach values 
Table 3. Average plagioclase compositions in Leg 153 gabbros.

\begin{tabular}{|c|c|c|c|c|c|c|c|c|c|c|c|}
\hline $\begin{array}{l}\text { Core, section, } \\
\text { interval }(\mathrm{cm})\end{array}$ & $n$ & $\mathrm{SiO}_{2}$ & $\mathrm{Al}_{2} \mathrm{O}_{3}$ & $\mathrm{FeO}$ & $\mathrm{MgO}$ & $\mathrm{CaO}$ & $\mathrm{Na}_{2} \mathrm{O}$ & $\mathrm{K}_{2} \mathrm{O}$ & Total & An & 1 s.d. \\
\hline $\begin{array}{l}153-923 A- \\
2 R-1,8-12 \\
3 R-1,138-141 \\
4 R-1,35-37 \\
4 R-1,127-131 \\
5 R-1,58-63 \\
5 R-2,0-5 \\
5 R-3,0-6 \\
6 R-2,18-23 \\
7 R-2,34-40 \\
8 R-1,61-65 \\
8 R-2,96-100 \\
9 R-1,135-141 \\
9 R-3,10-15 \\
10 R-2,122-127 \\
11 R-2,129-135 \\
12 R-1,24-28 \\
12 R-1,115-120 \\
13 R-1,65-69 \\
14 R-1,36-40 \\
15 R-2,114-118 \\
15 R-3,21-25 \\
16 R-3,5-9 \\
16 R-4,17-21\end{array}$ & $\begin{array}{r}9 \\
9 \\
9 \\
8 \\
9 \\
9 \\
9 \\
8 \\
8 \\
18 \\
9 \\
8 \\
8 \\
8 \\
9 \\
9 \\
8 \\
8 \\
8 \\
8 \\
9 \\
9 \\
8 \\
9\end{array}$ & $\begin{array}{l}56.43 \\
53.34 \\
56.33 \\
53.34 \\
53.96 \\
54.00 \\
53.83 \\
52.51 \\
51.18 \\
52.28 \\
53.19 \\
53.00 \\
53.42 \\
52.64 \\
48.95 \\
49.94 \\
49.67 \\
52.31 \\
51.90 \\
50.33 \\
49.96 \\
51.96 \\
51.76\end{array}$ & $\begin{array}{l}27.57 \\
29.87 \\
28.06 \\
29.43 \\
29.04 \\
29.15 \\
29.33 \\
29.69 \\
31.42 \\
29.83 \\
29.76 \\
29.95 \\
29.82 \\
30.28 \\
32.47 \\
32.08 \\
32.05 \\
30.19 \\
30.31 \\
31.72 \\
31.69 \\
31.05 \\
30.83\end{array}$ & $\begin{array}{l}0.33 \\
0.22 \\
0.24 \\
0.28 \\
0.31 \\
0.29 \\
0.33 \\
0.27 \\
0.28 \\
0.27 \\
0.26 \\
0.31 \\
0.34 \\
0.31 \\
0.20 \\
0.25 \\
0.31 \\
0.23 \\
0.28 \\
0.23 \\
0.25 \\
0.25 \\
0.23\end{array}$ & $\begin{array}{l}0.04 \\
0.04 \\
0.02 \\
0.04 \\
0.04 \\
0.03 \\
0.04 \\
0.03 \\
0.03 \\
0.03 \\
0.03 \\
0.03 \\
0.05 \\
0.05 \\
0.05 \\
0.03 \\
0.05 \\
0.03 \\
0.02 \\
0.05 \\
0.03 \\
0.04 \\
0.03\end{array}$ & $\begin{array}{r}9.17 \\
12.09 \\
9.48 \\
11.44 \\
11.31 \\
11.59 \\
11.53 \\
11.87 \\
13.77 \\
12.21 \\
11.99 \\
12.47 \\
12.14 \\
12.42 \\
14.99 \\
14.38 \\
14.54 \\
12.39 \\
12.57 \\
14.26 \\
14.19 \\
13.55 \\
12.93\end{array}$ & $\begin{array}{l}6.35 \\
4.67 \\
6.19 \\
4.99 \\
5.04 \\
4.93 \\
4.95 \\
4.69 \\
3.63 \\
4.52 \\
4.70 \\
4.44 \\
4.58 \\
4.34 \\
2.95 \\
3.29 \\
3.22 \\
4.46 \\
4.32 \\
3.38 \\
3.42 \\
3.84 \\
4.16\end{array}$ & $\begin{array}{l}0.09 \\
0.05 \\
0.08 \\
0.07 \\
0.05 \\
0.05 \\
0.05 \\
0.04 \\
0.04 \\
0.06 \\
0.04 \\
0.04 \\
0.04 \\
0.04 \\
0.02 \\
0.02 \\
0.03 \\
0.04 \\
0.05 \\
0.02 \\
0.02 \\
0.03 \\
0.04\end{array}$ & $\begin{array}{r}99.98 \\
100.28 \\
100.40 \\
99.59 \\
99.75 \\
100.04 \\
100.06 \\
99.10 \\
100.35 \\
99.20 \\
99.97 \\
100.24 \\
100.39 \\
100.08 \\
99.63 \\
99.99 \\
99.87 \\
99.65 \\
99.45 \\
99.99 \\
99.56 \\
100.72 \\
99.98\end{array}$ & $\begin{array}{l}44.1 \\
58.7 \\
45.6 \\
55.7 \\
55.2 \\
56.3 \\
56.2 \\
58.2 \\
70.9 \\
59.7 \\
58.4 \\
60.7 \\
59.3 \\
61.1 \\
73.6 \\
70.6 \\
71.3 \\
60.4 \\
61.5 \\
69.9 \\
69.6 \\
66.0 \\
63.1\end{array}$ & $\begin{array}{l} \pm 0.9 \\
\pm 2.4 \\
\pm 0.9 \\
\pm 3.4 \\
\pm 1.6 \\
\pm 1.4 \\
\pm 1.8 \\
\pm 3.1 \\
\pm 6.0 \\
\pm 5.1 \\
\pm 2.1 \\
\pm 1.4 \\
\pm 2.6 \\
\pm 1.6 \\
\pm 4.8 \\
\pm 4.2 \\
\pm 5.1 \\
\pm 4.1 \\
\pm 6.8 \\
\pm 3.7 \\
\pm 4.7 \\
\pm 2.8 \\
\pm 4.5\end{array}$ \\
\hline $\begin{array}{l}153-921 \mathrm{~A}- \\
2 \mathrm{R}-1,127-131 \\
2 \mathrm{R}-2,12-15\end{array}$ & $\begin{array}{l}8 \\
9\end{array}$ & $\begin{array}{l}53.86 \\
54.51\end{array}$ & $\begin{array}{l}28.74 \\
28.57\end{array}$ & $\begin{array}{l}0.34 \\
0.32\end{array}$ & $\begin{array}{l}0.05 \\
0.04\end{array}$ & $\begin{array}{l}10.91 \\
10.60\end{array}$ & $\begin{array}{l}5.29 \\
5.53\end{array}$ & $\begin{array}{l}0.07 \\
0.07\end{array}$ & $\begin{array}{l}99.26 \\
99.64\end{array}$ & $\begin{array}{l}53.1 \\
51.2\end{array}$ & $\begin{array}{l} \pm 3.7 \\
\pm 3.5\end{array}$ \\
\hline $\begin{array}{l}153-921 \mathrm{~B}- \\
\text { 2R-1, } 120-124 \\
2 \mathrm{R}-2,89-93 \\
3 \mathrm{R}-1,144-147 \\
3 \mathrm{R}-2,71-75 \\
4 \mathrm{R}-1,52-57 \\
4 \mathrm{R}-2,25-30 \\
4 \mathrm{R}-2,122-126 \\
4 \mathrm{R}-3,90-96 \\
4 \mathrm{R}-4,1-5\end{array}$ & $\begin{array}{l}9 \\
8 \\
9 \\
9 \\
9 \\
8 \\
9 \\
9 \\
8\end{array}$ & $\begin{array}{l}53.98 \\
53.06 \\
53.66 \\
52.38 \\
49.94 \\
49.66 \\
50.05 \\
49.66 \\
48.95\end{array}$ & $\begin{array}{l}29.14 \\
29.81 \\
29.07 \\
30.40 \\
31.84 \\
31.69 \\
31.70 \\
32.03 \\
32.36\end{array}$ & $\begin{array}{l}0.30 \\
0.20 \\
0.37 \\
0.16 \\
0.19 \\
0.30 \\
0.40 \\
0.30 \\
0.33\end{array}$ & $\begin{array}{l}0.03 \\
0.03 \\
0.05 \\
0.08 \\
0.03 \\
0.04 \\
0.05 \\
0.05 \\
0.05\end{array}$ & $\begin{array}{l}11.20 \\
11.91 \\
11.10 \\
12.09 \\
14.07 \\
14.25 \\
13.89 \\
14.41 \\
14.86\end{array}$ & $\begin{array}{l}5.20 \\
4.82 \\
5.27 \\
4.63 \\
3.57 \\
3.42 \\
3.53 \\
3.36 \\
3.05\end{array}$ & $\begin{array}{l}0.09 \\
0.05 \\
0.07 \\
0.04 \\
0.04 \\
0.05 \\
0.04 \\
0.04 \\
0.04\end{array}$ & $\begin{array}{l}99.94 \\
99.88 \\
99.59 \\
99.78 \\
99.68 \\
99.41 \\
99.66 \\
99.85 \\
99.64\end{array}$ & $\begin{array}{l}54.1 \\
57.5 \\
53.6 \\
58.9 \\
68.4 \\
69.5 \\
68.3 \\
70.2 \\
72.7\end{array}$ & $\begin{array}{l} \pm 1.4 \\
\pm 1.1 \\
\pm 0.4 \\
\pm 2.0 \\
\pm 4.1 \\
\pm 3.0 \\
\pm 2.3 \\
\pm 2.5 \\
\pm 4.4\end{array}$ \\
\hline $\begin{array}{l}153-921 \mathrm{C}- \\
2 \mathrm{R}-2,70-75 \\
3 \mathrm{R}-1,108-110\end{array}$ & $\begin{array}{l}8 \\
9\end{array}$ & $\begin{array}{l}51.81 \\
49.88\end{array}$ & $\begin{array}{l}30.66 \\
31.41\end{array}$ & $\begin{array}{l}0.29 \\
0.33\end{array}$ & $\begin{array}{l}0.04 \\
0.04\end{array}$ & $\begin{array}{l}12.74 \\
13.63\end{array}$ & $\begin{array}{l}4.31 \\
3.76\end{array}$ & $\begin{array}{l}0.07 \\
0.05\end{array}$ & $\begin{array}{l}99.92 \\
99.10\end{array}$ & $\begin{array}{l}61.8 \\
66.5\end{array}$ & $\begin{array}{l} \pm 4.9 \\
\pm 4.3\end{array}$ \\
\hline $\begin{array}{l}153-921 \mathrm{D}- \\
2 \mathrm{R}-1,13-18 \\
2 \mathrm{R}-1,67-71 \\
5 \mathrm{R}-2,0-4 \\
5 \mathrm{R}-2,0-4 \text { ox }\end{array}$ & $\begin{array}{l}8 \\
8 \\
7 \\
8\end{array}$ & $\begin{array}{l}52.71 \\
55.42 \\
52.75 \\
57.51\end{array}$ & $\begin{array}{l}29.54 \\
28.06 \\
29.89 \\
26.53\end{array}$ & $\begin{array}{l}0.34 \\
0.30 \\
0.27 \\
0.35\end{array}$ & $\begin{array}{l}0.04 \\
0.04 \\
0.03 \\
0.04\end{array}$ & $\begin{array}{r}11.69 \\
10.02 \\
12.00 \\
8.21\end{array}$ & $\begin{array}{l}4.84 \\
5.75 \\
4.67 \\
6.84\end{array}$ & $\begin{array}{l}0.06 \\
0.07 \\
0.07 \\
0.13\end{array}$ & $\begin{array}{l}99.22 \\
99.66 \\
99.68 \\
99.61\end{array}$ & $\begin{array}{l}57.0 \\
49.0 \\
58.4 \\
39.6\end{array}$ & $\begin{array}{l} \pm 4.2 \\
\pm 1.2 \\
\pm 3.7 \\
\pm 0.4\end{array}$ \\
\hline $\begin{array}{l}153-921 \mathrm{E}- \\
2 \mathrm{R}-1,100-105 \\
2 \mathrm{R}-2,8-12 \\
3 \mathrm{R}-1,19-24 \\
3 \mathrm{R}-1,81-85 \\
5 \mathrm{R}-2,19-24 \\
5 \mathrm{R}-3,32-36 \\
5 \mathrm{R}-3,32-36 \\
6 \mathrm{R}-1,101-106 \\
7 \mathrm{R}-2,12-17 \\
7 \mathrm{R}-4,68-72\end{array}$ & $\begin{array}{l}9 \\
8 \\
8 \\
9 \\
9 \\
6 \\
8 \\
9 \\
9 \\
9\end{array}$ & $\begin{array}{l}52.45 \\
52.81 \\
55.30 \\
51.97 \\
51.43 \\
50.61 \\
51.24 \\
51.34 \\
51.69 \\
50.32\end{array}$ & $\begin{array}{l}29.63 \\
30.01 \\
27.72 \\
30.60 \\
30.86 \\
31.28 \\
31.12 \\
30.90 \\
31.03 \\
31.24\end{array}$ & $\begin{array}{l}0.26 \\
0.29 \\
0.22 \\
0.19 \\
0.25 \\
0.26 \\
0.26 \\
0.28 \\
0.32 \\
0.23\end{array}$ & $\begin{array}{l}0.03 \\
0.03 \\
0.02 \\
0.02 \\
0.04 \\
0.04 \\
0.04 \\
0.06 \\
0.05 \\
0.04\end{array}$ & $\begin{array}{r}11.86 \\
12.10 \\
9.84 \\
12.63 \\
13.26 \\
13.70 \\
13.29 \\
13.20 \\
13.35 \\
13.63\end{array}$ & $\begin{array}{l}4.79 \\
4.61 \\
5.91 \\
4.31 \\
3.98 \\
3.73 \\
4.00 \\
3.98 \\
3.85 \\
3.73\end{array}$ & $\begin{array}{l}0.07 \\
0.06 \\
0.10 \\
0.05 \\
0.03 \\
0.04 \\
0.04 \\
0.03 \\
0.05 \\
0.03\end{array}$ & $\begin{array}{r}99.09 \\
99.91 \\
99.11 \\
99.77 \\
99.85 \\
99.66 \\
99.99 \\
99.79 \\
100.34 \\
99.22\end{array}$ & $\begin{array}{l}57.6 \\
59.0 \\
47.7 \\
61.7 \\
64.7 \\
67.0 \\
64.6 \\
64.6 \\
65.5 \\
66.7\end{array}$ & $\begin{array}{l} \pm 4.7 \\
\pm 2.2 \\
\pm 4.5 \\
\pm 5.3 \\
\pm 1.5 \\
\pm 2.0 \\
\pm 3.2 \\
\pm 2.6 \\
\pm 5.6 \\
\pm 5.4\end{array}$ \\
\hline $\begin{array}{l}153-922 \mathrm{~A}- \\
2 \mathrm{R}-5,125-129 \\
3 \mathrm{R}-1,23-27 \text { ox } \\
3 \mathrm{R}-1,23-27\end{array}$ & $\begin{array}{l}8 \\
8 \\
7\end{array}$ & $\begin{array}{l}48.41 \\
55.70 \\
48.30\end{array}$ & $\begin{array}{l}33.04 \\
27.97 \\
33.12\end{array}$ & $\begin{array}{l}0.18 \\
0.30 \\
0.25\end{array}$ & $\begin{array}{l}0.02 \\
0.02 \\
0.03\end{array}$ & $\begin{array}{r}15.56 \\
9.86 \\
15.70\end{array}$ & $\begin{array}{l}2.63 \\
5.89 \\
2.59\end{array}$ & $\begin{array}{l}0.03 \\
0.09 \\
0.03\end{array}$ & $\begin{array}{r}99.87 \\
99.83 \\
100.02\end{array}$ & $\begin{array}{l}76.6 \\
48.1 \\
77.0\end{array}$ & $\begin{array}{l} \pm 3.4 \\
\pm 4.2 \\
\pm 3.3\end{array}$ \\
\hline $\begin{array}{c}153-922 \mathrm{~B}- \\
\text { IW-1. 37-40 } \\
2 \mathrm{R}-2,17-21\end{array}$ & $\begin{array}{l}8 \\
8\end{array}$ & $\begin{array}{l}48.90 \\
48.38\end{array}$ & $\begin{array}{l}32.21 \\
32.44\end{array}$ & $\begin{array}{l}0.17 \\
0.13\end{array}$ & $\begin{array}{l}0.03 \\
0.04\end{array}$ & $\begin{array}{l}15.09 \\
15.38\end{array}$ & $\begin{array}{l}2.88 \\
2.70\end{array}$ & $\begin{array}{l}0.05 \\
0.04\end{array}$ & $\begin{array}{l}99.33 \\
99.11\end{array}$ & $\begin{array}{l}74.1 \\
75.7\end{array}$ & $\begin{array}{l} \pm 2.8 \\
\pm 3.1\end{array}$ \\
\hline
\end{tabular}

Notes: All data are given in wt $\%$; " $n$ " is the number of analyses per sample; s.d. = standard deviation. An is anorthite, $(100 \cdot \mathrm{Ca} /[\mathrm{Ca}+\mathrm{Na}+\mathrm{K}]$, molar units $)$. In samples with primary oxide veins, "ox" adjacent to sample name indicates that these analyses were within the vein or proximal to oxides, the second line with the same sample name is the average of analyses obtained distal to the oxide vein.

as high as those in the residual mantle samples. This feature suggests minimal fractionation of $\mathrm{Cr}$ spinel from these magmas before crystallization of these samples.

Figure 5 shows $\mathrm{Mg \#}$ vs. $\mathrm{Na}_{2} \mathrm{O}$ in clinopyroxene. All samples, except one, plot on a trend of moderately increasing sodium with decreasing Mg\#. The lone outlier on this plot is a sample (Sample 153$923 \mathrm{~A}-7 \mathrm{R}-2,34-40 \mathrm{~cm}$ ) in which clinopyroxene is remarkably enriched in $\mathrm{Zr}$ and other trace elements (see below). Aside from this sample, it appears from this plot that this suite could plausibly represent crystal fractionation from a single parental magma. It will be shown, however, on the basis of ion probe data for clinopyroxene in these gabbroic rocks that heterogeneity in parental magma trace-element composition is required. Shown for comparison in Figure 5 are fields for other suites of oceanic cumulates, including the Mid-Cayman Rise (Elthon, 1987), Leg 118 (Hébert et al., 1991), and Deep Sea Drilling Project Site 334 (Hodges and Papike, 1976; Ross and Elthon, 1993). Sodium oxide in clinopyroxene in Leg 153 gabbros is similar to the lowermost contents in Leg 118 and Mid-Cayman Rise gabbros. Inferred parental magma compositions will be discussed in a later section. 


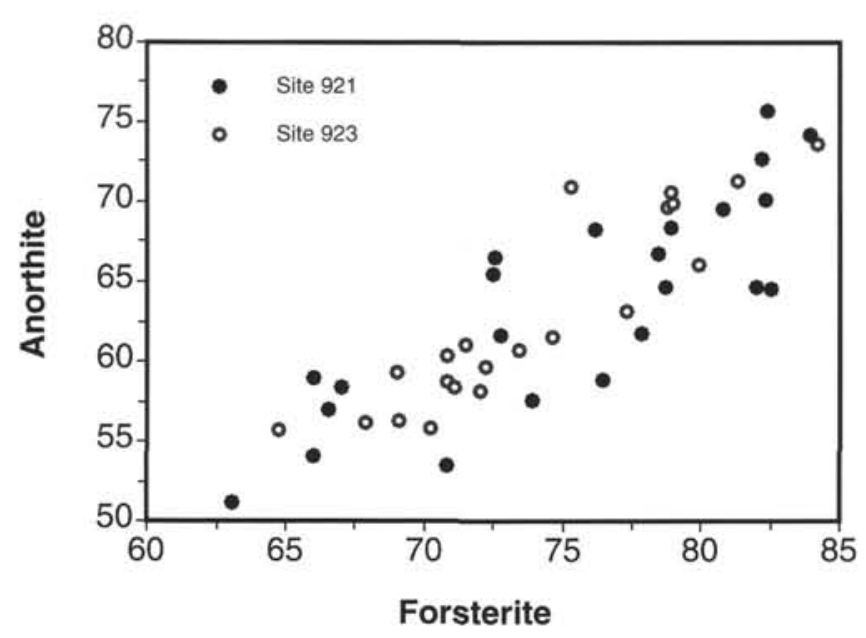

Figure 1. Mean forsterite in olivine vs. mean anorthite in plagioclase in Leg 153 gabbroic rocks.

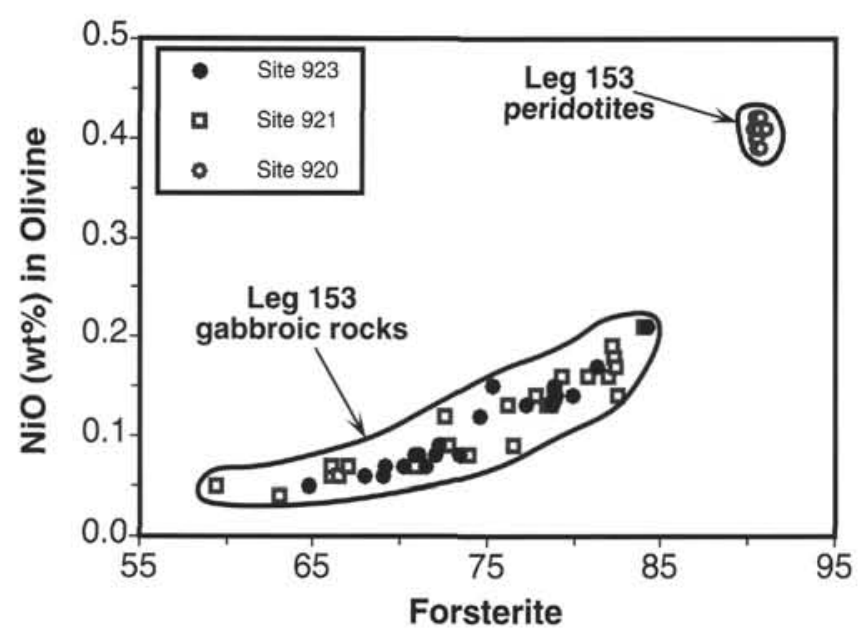

Figure 2. Mean forsterite in olivine vs. $\mathrm{NiO}$ in olivine in Leg 153 gabbros and in residual peridotites from Site 920 .

In contrast to the plot of $\mathrm{Mg \#} \mathrm{vs.} \mathrm{Na}_{2} \mathrm{O}$ in clinopyroxene shown in Figure 5, which showed essentially a single trend, at least two distinct trends are clear in Figure 6, a plot of $\mathrm{Mg \#}$ vs. $\mathrm{TiO}_{2}$ in clinopyroxene. The bulk of the poikilitic olivine gabbros define a trend with steeply increasing $\mathrm{TiO}_{2}$ as $\mathrm{Mg} \#$ decreases, and a second, more gently increasing trend is defined by the olivine gabbros with cumulus-textured clinopyroxene and by the oxide gabbronorites. These trends are labeled "postcumulus trend" and "cumulus trend," respectively, in Figure 6. Clinopyroxenes with the lowest $\mathrm{TiO}_{2}$ in poikilitic olivine gabbros fall at or near the intersection of these two trends. From these data, it is inferred that melt in the interstitial pore space of rocks with postcumulus clinopyroxene followed an evolutionary path distinct from that taken by the main magma, which deposited rocks that define the "cumulus trend." It appears that evolving, crystallizing, interstitial melt is, to some degree, buffered in major-element contents by continuing equilibration with magnesian cumulus mafic phases, whereas incompatible trace-element contents in pore melts (such as Ti) are enriched by melt-mass reduction as the pore melt crystallizes. In samples that show Ti-enrichment in poikilitic clinopyroxene, $\mathrm{TiO}_{2}$ varies by a factor of $>3$, whereas $\mathrm{Mg} \#$ varies by 3-4 units. Zoning profiles and corerim pairs in clinopyroxene show that $\mathrm{Mg} \#$ varies minimally, whereas $\mathrm{TiO}_{2}$ increases in the rim by a factor of 3 to 4 . It is possible that poikil-

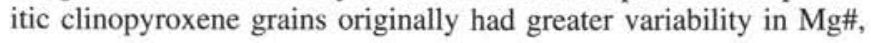

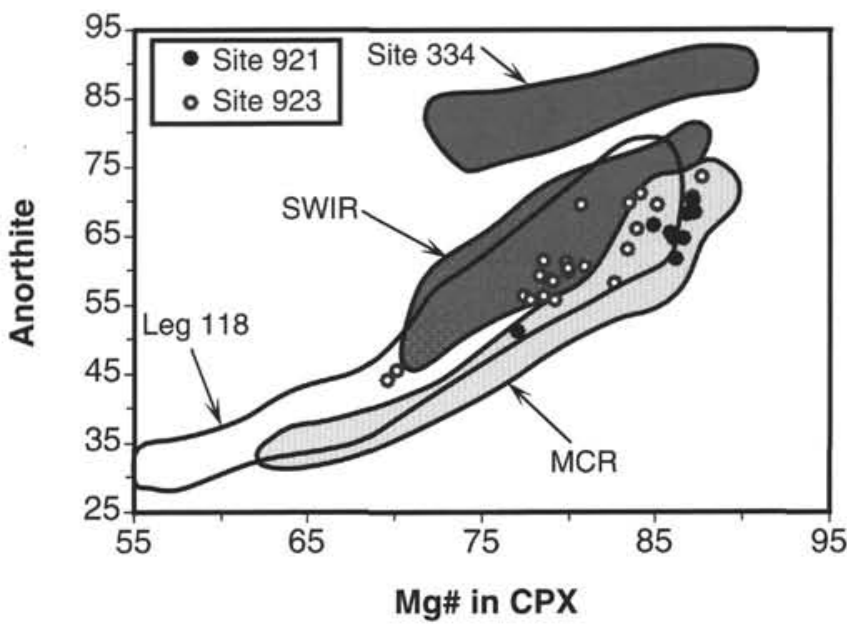

Figure 3. Mean anorthite in plagioclase vs. $\mathrm{Mg} \#$ in clinopyroxene (CPX) in Leg 153 gabbros and other suites of oceanic cumulates. SWIR is the Southwest Indian Ridge (data from Meyer et al., 1989), MCR is the Mid-Cayman Rise (data from Elthon, 1987), Site 334 data are from Hodges and Papike (1976) and Ross and Elthon (1993), and Leg 118 data are from Hébert et al., (1991).

and that subsolidus equilibration by diffusion of $\mathrm{Fe}$ and $\mathrm{Mg}$ within clinopyroxene grains has reduced this variability, whereas tetravalent species such as Ti cannot readily diffuse over the distances required to smooth out their compositional variations. Evolution of pore melts by crystallization of intercumulus phases, with buffering of majorelement ratios such as $\mathrm{Fe} / \mathrm{Mg}$ by equilibration with mafic cumulus phases, could explain the apparent premature appearance of ilmenite in rocks with very magnesian cumulus olivine and clinopyroxene compositions.

Compositions of orthopyroxene in Leg 153 gabbros are listed in Table 5. Orthopyroxene is an abundant phase in oxide gabbronorites (Samples 153-923A-2R-1, 8-12 cm, and 4R-1, 35-37 cm; see Table 1 for modal data) and is an accessory phase, occurring as rims on olivine grains in some other cumulate rocks at Site 923. Mean $\mathrm{Mg} \#$ in orthopyroxene ranges from 75.3 to 64.4 .

Table 6 shows mean compositions of oxide phases in these rocks. Data are presented for disseminated ilmenite that occurs in olivine gabbro and poikilitic olivine gabbro. A mixture of exsolved ilmenite and magnetite occurs in oxide-rich veins or layers that have oxidegabbronorite mineralogy. Samples with magnetite compositions reported in Table 6 are oxide-rich samples. Those with ilmenite but no magnetite are samples in which oxide minerals are disseminated accessory phases, rather than essential major constituents of the crystallizing assemblage. In some cases, oxide-rich samples clearly are veins that crosscut fabrics or layering in host gabbroic rocks. In other cases, it is unclear whether these samples represent veins or oxidegabbro cumulate layers. Zirconia, presumably the monoclinic form baddeleyite (Smith and Newkirk, 1965), has been observed as a trace accessory phase $(<<1 \%)$ in eleven samples in this suite of gabbroic rocks. Baddeleyite has been reported associated with ilmenite in oceanic gabbroic rocks from the Mathematician Ridge (Batiza and Vanko, 1985). Natural occurrences of baddeleyite are reviewed in Haggerty (1987). Baddeleyite has been reported in gabbroic rocks in the Rhum intrusion by Williams (1978), in kimberlites by ScatenaWachel and Jones (1984), and in gabbroic rocks from Axel Heiberg Island and in Hawaiian alkali basalts by Keil and Fricker (1974). Compositions of baddeleyite in two samples are shown in Table 6. Titanium and hafnium are the dominant substituting cations in this phase. Baddeleyite in this suite is invariably observed in association with ilmenite, but does not exhibit a readily recognizable exsolution texture. Baddeleyite could have formed as an exsolution product from ilmenite, as a late-stage phase crystallizing from trapped melt, 
Table 4. Average clinopyroxene compositions in Leg 153 gabbros.

\begin{tabular}{|c|c|c|c|c|c|c|c|c|c|c|c|c|c|c|}
\hline $\begin{array}{l}\text { Core, section, } \\
\text { interval }(\mathrm{cm})\end{array}$ & $n$ & $\mathrm{SiO}_{2}$ & $\mathrm{TiO}_{2}$ & $\mathrm{Al}_{2} \mathrm{O}_{3}$ & $\mathrm{Cr}_{2} \mathrm{O}_{3}$ & $\mathrm{FeO}$ & $\mathrm{MnO}$ & $\mathrm{MgO}$ & $\mathrm{CaO}$ & $\mathrm{Na}_{2} \mathrm{O}$ & $\mathrm{NiO}$ & Total & $\mathrm{Mg \#}$ & 1 s.d. \\
\hline \multicolumn{15}{|l|}{$153-923 \mathrm{~A}-$} \\
\hline $2 \mathrm{R}-1,8-12$ & 6 & 51.73 & 0.73 & 2.29 & 0.01 & 10.93 & 0.35 & 14.00 & 19.56 & 0.45 & 0.01 & 100.06 & 69.6 & \pm 0.82 \\
\hline $3 R-1,138-141$ & 8 & 52.20 & 0.69 & 2.58 & 0.12 & 7.82 & 0.24 & 16.35 & 19.59 & 0.37 & 0.01 & 99.97 & 78.9 & \pm 0.80 \\
\hline $4 \mathrm{R}-1,35-37$ & 6 & 52.04 & 0.73 & 2.23 & 0.02 & 10.54 & 0.40 & 13.88 & 20.13 & 0.44 & 0.01 & 100.42 & 70.1 & \pm 0.90 \\
\hline $4 \mathrm{R}-1,127-131$ & 8 & 52.25 & 0.73 & 2.56 & 0.05 & 7.76 & 0.24 & 15.25 & 20.14 & 0.40 & 0.01 & 99.39 & 77.8 & \pm 1.18 \\
\hline SR-1, 58-63 & 7 & 52.25 & 0.66 & 2.57 & 0.05 & 7.76 & 0.24 & 16.56 & 19.54 & 0.37 & 0.01 & 100.01 & 79.2 & \pm 1.29 \\
\hline SR-2, 0-5 & 8 & 51.98 & 0.70 & 2.54 & 0.07 & 7.92 & 0.24 & 15.44 & 20.61 & 0.42 & 0.01 & 99.93 & 77.7 & \pm 1.22 \\
\hline $5 R-3,0-6$ & 7 & 51.90 & 0.64 & 2.57 & 0.04 & 8.29 & 0.24 & 15.92 & 20.01 & 0.39 & 0.01 & 100.01 & 77.4 & \pm 1.19 \\
\hline $6 \mathrm{R}-2,18-23$ & 6 & 52.73 & 0.53 & 2.63 & 0.18 & 6.47 & 0.19 & 17.23 & 19.25 & 0.35 & 0.01 & 99.57 & 82.6 & \pm 1.91 \\
\hline $7 \mathrm{R}-2,34-40$ & 9 & 51.06 & 0.93 & 3.27 & 0.35 & 6.50 & 0.21 & 15.27 & 21.31 & 0.53 & 0.02 & 99.45 & 80.7 & \pm 0.93 \\
\hline $8 \mathrm{R}-1,61-65$ & 8 & 52.43 & 0.63 & 2.68 & 0.11 & 7.37 & 0.22 & 16.42 & 19.86 & 0.37 & 0.01 & 100.10 & 79.9 & \pm 1.64 \\
\hline $8 \mathrm{R}-2,96-100$ & 8 & 52.35 & 0.73 & 2.48 & 0.10 & 7.51 & 0.22 & 15.95 & 20.57 & 0.35 & 0.02 & 100.28 & 79.1 & \pm 1.96 \\
\hline $9 \mathrm{R}-1,135-141$ & 9 & 52.42 & 0.57 & 2.82 & 0.17 & 7.18 & 0.20 & 17.04 & 19.34 & 0.37 & 0.02 & 100.13 & 80.9 & \pm 1.34 \\
\hline $9 \mathrm{R}-3,10-15$ & 8 & 52.08 & 0.62 & 2.66 & 0.13 & 8.10 & 0.23 & 16.34 & 19.51 & 0.38 & 0.01 & 100.06 & 78.3 & \pm 2.21 \\
\hline $10 \mathrm{R}-2,122-127$ & 8 & 52.23 & 0.53 & 2.77 & 0.16 & 7.59 & 0.20 & 16.77 & 19.49 & 0.35 & 0.02 & 100.11 & 79.8 & \pm 1.46 \\
\hline $11 \mathrm{R}-2,129-135$ & 8 & 52.22 & 0.52 & 3.68 & 1.07 & 4.35 & 0.15 & 17.35 & 20.38 & 0.38 & 0.04 & 100.14 & 87.7 & \pm 0.79 \\
\hline $12 \mathrm{R}-1,24-28$ & 8 & 52.04 & 0.52 & 3.65 & 0.99 & 4.48 & 0.15 & 16.97 & 20.80 & 0.36 & 0.03 & 99.99 & 87.1 & \pm 1.51 \\
\hline $12 \mathrm{R}-1,115-120$ & 8 & 52.04 & 1.06 & 3.29 & 0.12 & 5.51 & 0.17 & 16.36 & 21.02 & 0.37 & 0.02 & 99.96 & 84.1 & \pm 1.53 \\
\hline $13 \mathrm{R}-1,65-69$ & 8 & 51.87 & 0.60 & 3.08 & 0.47 & 7.19 & 0.20 & 16.03 & 20.38 & 0.39 & 0.02 & 100.23 & 79.9 & \pm 2.82 \\
\hline $14 \mathrm{R}-1,36-40$ & 8 & 50.67 & 1.05 & 3.29 & 0.13 & 7.46 & 0.23 & 15.27 & 20.62 & 0.39 & 0.02 & 99.13 & 78.5 & \pm 3.05 \\
\hline $15 R-2,114-118$ & 6 & 51.79 & 0.74 & 3.10 & 0.42 & 5.68 & 0.18 & 16.11 & 20.95 & 0.38 & 0.02 & 99.37 & 83.5 & \pm 0.60 \\
\hline $15 \mathrm{R}-3,21-25$ & 8 & 51.58 & 0.55 & 3.43 & 0.75 & 5.23 & 0.17 & 16.74 & 20.66 & 0.40 & 0.02 & 99.53 & 85.1 & \pm 1.41 \\
\hline $16 \mathrm{R}-3,5-9$ & 7 & 52.11 & 0.72 & 2.92 & 0.12 & 5.81 & 0.19 & 17.05 & 20.62 & 0.33 & 0.02 & 99.89 & 83.9 & \pm 0.68 \\
\hline $16 R-4,17-21$ & 8 & 51.56 & 0.67 & 3.14 & 0.40 & 5.70 & 0.18 & 16.07 & 21.39 & 0.37 & 0.03 & 99.51 & 83.4 & \pm 1.95 \\
\hline \multicolumn{15}{|l|}{$153-921 \mathrm{~A}-$} \\
\hline & 0 & \$1.00 & 10 & 2.50 & 74 & ל & 20 & 4 & ... & 9 & 01 & 50 & 9.00 & -8.00 \\
\hline \multicolumn{15}{|l|}{ 153-921B- } \\
\hline $4 \mathrm{R}-1,52-57$ & 8 & 52.33 & 0.39 & 3.58 & 0.17 & $\begin{array}{l}0.35 \\
447\end{array}$ & 0.20 & 17.14 & $\begin{array}{l}19.01 \\
20.23\end{array}$ & 0.34 & 0.01 & 99.40 & 82.8 & \pm 0.44 \\
\hline $4 \mathrm{R}-2,122-126$ & 8 & 51.98 & 0.41 & 3.29 & 0.91 & 4.41 & 0.15 & 17.42 & $\begin{array}{l}20.23 \\
20.13\end{array}$ & 0.38 & 0.03 & 99.70 & 87.2 & \pm 1.29 \\
\hline $4 R-3,90-96$ & 9 & 51.97 & 0.52 & 3.38 & 0.72 & 4.64 & 0.15 & 17.60 & 20.37 & 0.34 & 0.03 & 99.72 & $\begin{array}{l}80.8 \\
87.1\end{array}$ & $\begin{array}{l} \pm 2.43 \\
\pm 1.02\end{array}$ \\
\hline \multicolumn{15}{|l|}{$153-921 \mathrm{C}$ - } \\
\hline 2R-2, 70-75 & 8 & 52.39 & 0.55 & 3.20 & 0.60 & 4.87 & 0.15 & 17.10 & 20.21 & 0.36 & 0.02 & 99.45 & 86.2 & \pm 1.61 \\
\hline $3 \mathrm{R}-1,108-110$ & 7 & 51.88 & 0.52 & 3.51 & 0.88 & 5.36 & 0.17 & 16.83 & 19.90 & 0.38 & 0.03 & 99.46 & 84.9 & \pm 3.50 \\
\hline \multicolumn{15}{|l|}{$153-921 \mathrm{E}-$} \\
\hline SR-2, 19-24 & 8 & 52.54 & 0.43 & 3.02 & 0.32 & 5.10 & 0.17 & 17.70 & 19.79 & 0.33 & 0.03 & 99.43 & 86.1 & \pm 0.44 \\
\hline $6 \mathrm{R}-1,101-106$ & 9 & 52.52 & 0.42 & 3.09 & 0.41 & 4.81 & 0.15 & 17.44 & 20.45 & 0.33 & 0.03 & 99.65 & 86.6 & \pm 0.90 \\
\hline $7 R-2,12-17$ & 8 & 51.60 & 0.47 & 3.41 & 0.58 & 5.13 & 0.15 & 17.37 & 20.24 & 0.36 & 0.02 & 99.33 & 85.8 & \pm 1.85 \\
\hline
\end{tabular}

Notes: All data are given in wt \%; " $n$ " is the number of analyses per sample; s.d. = standard deviation. $\mathrm{Mg} \#$ is $100 \cdot \mathrm{Mg} /(\mathrm{Mg}+\mathrm{Fe})$, with all iron as FeO.

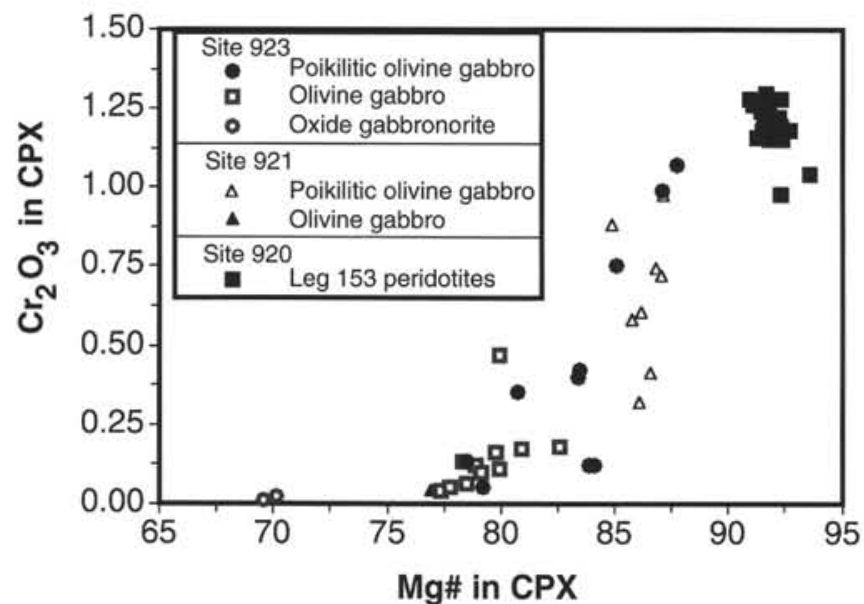

Figure 4. $\mathrm{Mg \#}$ vs. $\mathrm{Cr}_{2} \mathrm{O}_{3}$ (wt \%) in clinopyroxene (CPX) in Leg 153 gabbroic rocks and residual peridotites.

or by crystallizing from $\mathrm{Zr}-$, $\mathrm{P}$ - and Fe-enriched immiscible melt formed by unmixing of very evolved intercumulus melt. Apatite compositions are reported in Table 7. Apatite is a trace phase in all samples in which it occurs, except in some oxide gabbronorites, where its modal abundance can reach levels that suggest apatite is a cumulus phase. Apatites consist mainly of solid solutions of fluorapatite and hydroxyapatite, with generally low levels of $\mathrm{Cl}^{-}$. Those samples with somewhat higher chlorine were recovered at Site 922. The holes at Site 922 recovered rock that generally have much higher degrees of hydrothermal alteration than rocks from Sites 921 and

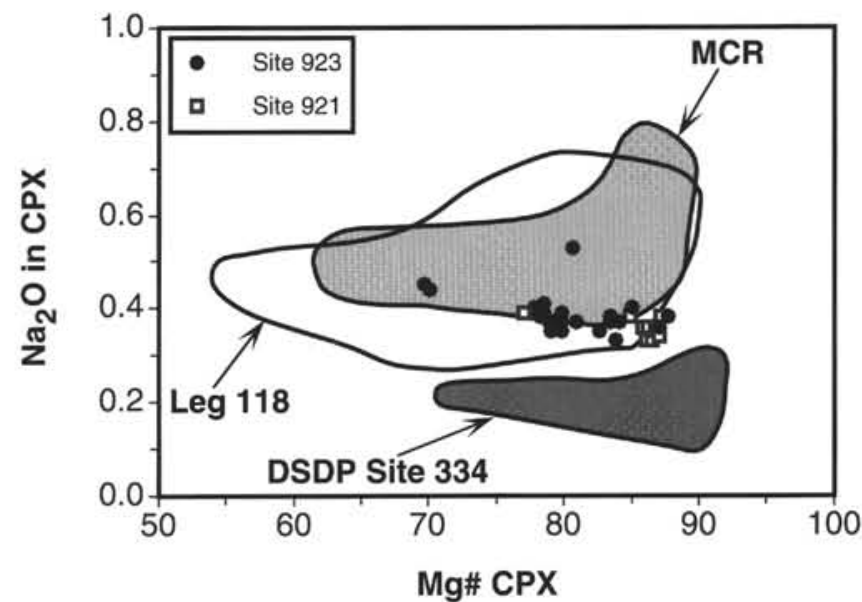

Figure 5. $\mathrm{Mg \#} \mathrm{vs.} \mathrm{Na}_{2} \mathrm{O}$ (wt\%) in clinopyroxene (CPX) in Leg 153 gabbroic rocks and other oceanic cumulates. Data sources are as in Figure 4.

923, and it is possible that the high chlorine in these apatites was attained during intense alteration.

\section{INAA AND ION PROBE RESULTS}

We obtained INAA data for gabbro whole rocks from Sites 921 to 923 , and for clinopyroxene and plagioclase separates from selected samples (mostly from Site 923). INAA data for clinopyroxene separates are shown in Table 8. Plagioclase data appear in Table 9 and 
whole-rock data are in Table 10. Chondrite-normalized REE patterns of clinopyroxene separates are displayed in Figure 7, plagioclase separates in Figure 8, and whole-rock patterns in Figures 9A-9G. The most striking feature of rare-earth abundances in mineral separates is the great variability within this suite. La in clinopyroxene varies by a factor of 11 , and by a factor of 8 in plagioclase in rocks in which the $\mathrm{Mg} \#$ in clinopyroxene varies from 88 to 70 . Heavy REE abundances are also quite variable in clinopyroxene mineral separates, ranging from 5 to $30 \times$ chondrite. As discussed in the previous section, the extent of crystallization required to produce the observed changes in major-element compositions of minerals in these gabbroic rocks is $50 \%$, assuming fractionation of a single parental magma. Perfectly incompatible-element concentrations would increase in related evolving melts and crystals formed from these melts by a factor of about 2 over this extent of crystallization, yet these minerals vary by a factor of 10 . Thus, either these rocks are not all related by simple fractional crystallization to a single parental melt, or postcumulus processes in these rocks have enriched some rocks and minerals in incompatible elements, or indeed some combination of these effects could have operated. A critical problem in using cumulate rocks to make inferences about melt compositions is to distinguish geochemical variations that reflect primary cumulus stage processes from those that are caused by postcumulus effects. The data in this paper show that any attempt to resolve this issue requires the trace-element microanalytical techniques of the ion probe. Only by examining intrasample and intragrain variations in mineral compositions can this problem be resolved.

Comparing trace-element abundances in clinopyroxene determined by ion probe to the bulk analyses determined by INAA shows that clinopyroxenes in individual samples have a range of compositions that extends to values substantially lower than the bulk analy-

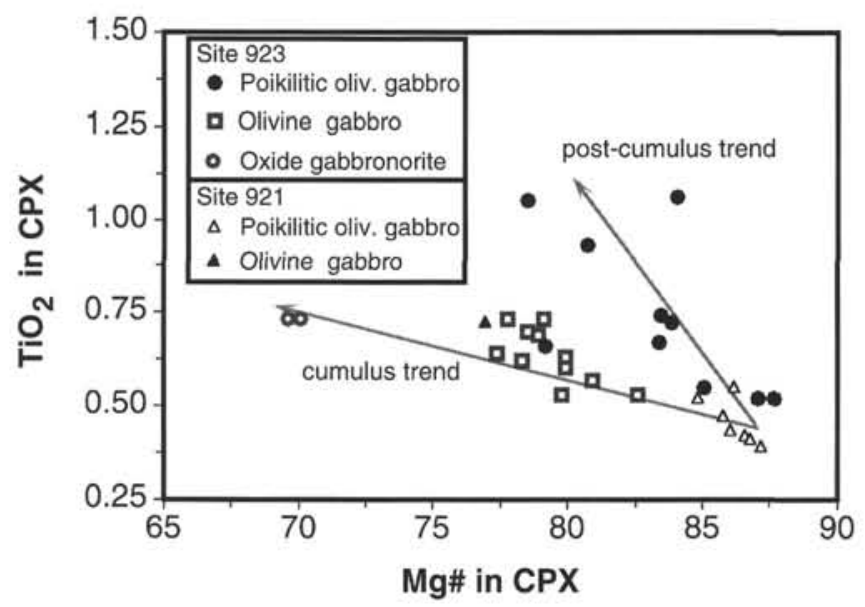

Figure 6. $\mathrm{Mg \#} \mathrm{vs.} \mathrm{TiO}_{2}$ (wt\%) in clinopyroxene (CPX) in Leg 153 gabbroic rocks. The "cumulus trend" is consistent with fractional crystallization; the "postcumulus trend" is defined by samples in which clinopyroxene has intercumulus or poikilitic textures, and is attributed to crystallization from evolving intercumulus melts buffered at high $\mathrm{Mg} \#$ by interaction with cumulus crystals (further discussion in text). ses. This suggests that the bulk analyses cannot be used to adequately characterize the parental magmas of these rocks. Growth of trace-element-enriched rims or zones on cumulus minerals leads to an overall increase in incompatible trace-element concentrations in bulk-mineral separates and in bulk-rock analyses. For example, in Sample 153$923 \mathrm{~A}-12 \mathrm{R}-1,24-28 \mathrm{~cm}$, a poikilitic olivine gabbro, spot analyses of La in clinopyroxene vary from 0.05 to $0.19 \mathrm{ppm}$, and spot analyses of $\mathrm{Zr}$ vary from 5 to $14 \mathrm{ppm}$; the bulk analysis of $\mathrm{La}$ in clinopyroxene is $0.12 \mathrm{ppm}$. Note that some core analyses are enriched by a factor of $>2$ in REE and $\mathrm{Zr}$ relative to the most depleted spots. Trace-element enrichments occur not only at the rims but also in some cores. If a constant $\mathrm{D}$ value for clinopyroxene/melt partitioning of $\mathrm{La}$ is assumed, the parental melt calculated from the bulk analysis would, therefore, overestimate the La contents of the most primitive melt that crystallized this sample by a factor of more than 2. Comparison of ion probe and INAA data for those other samples for which we have both data types shows similar enrichments in some spot analyses and in the overall bulk analyses. It appears that attempting to estimate parental melts from this suite using bulk analyses produces upper limits on the parental melt composition, rather than an accurate measure of the original parental melt. In some samples, bulk separates are only slightly enriched relative to the more depleted group of ion probe analyses, but to derive the best estimates of parental melt compositions, we use ion probe data. We attribute the large variability of trace-element contents within individual samples and grains to evolution of intercumulus melt, rather than to large variations in original parental melt compositions.

As with titanium in clinopyroxene, $\mathrm{Zr}$ and REEs in clinopyroxene vary by factors of $2-5$ in individual samples, whereas major-element variations such as $\mathrm{Mg \#}$ change by amounts that are consistent with only $10 \%-20 \%$ crystallization of intercumulus melt. As noted above, buffering of intercumulus melt major-element compositions inhibits the deposition of low- $\mathrm{Mg} \#$ clinopyroxene in these pore spaces, whereas incompatible trace elements are free to vary by much larger extents. For bulk clinopyroxene separates, those samples with $\mathrm{La}_{\mathrm{n}}<2$ $\times$ chondrite have relatively minor enrichments in REEs, but the three mineral separates with $\mathrm{La}_{\mathrm{n}}$ at 3 to $5 \times$ chondrite have probably been strongly enriched in REEs because of postcumulus processes. At this stage in our investigation of these rocks, the large range in trace-element abundances in bulk separates appears to be largely a consequence of postcumulus effects, rather than being attributed to extreme variability in parental melt compositions, although some evidence for heterogeneity in parental magmas is also observed.

Convincing evidence for variability in parental melts compositions can be seen by comparing clinopyroxene trace-element abundances determined by ion probe in Sample 153-923A-12R-1, 24-28 $\mathrm{cm}$, with those in Samples 15R-2, 114-188 cm, and 5R-1, 58-63 cm. The most depleted analysis in Sample 12R-1-24-28 is lower by a factor of 6 in $\mathrm{La}$, by a factor of 2 in $\mathrm{Yb}$, and by a factor of 3 in $\mathrm{Zr}$ (see Table 11), relative to the more enriched samples. The most depleted subset of analyses in these samples record the parental magma compositions and enriched analyses within the same samples are the result of postcumulus effects. Estimates of parental melts compositions, based on the use of clinopyroxene/liquid Ds to calculate liquids in equilibrium with the depleted clinopyroxene, are displayed in Table 12. Two parental melt compositions are estimated in Table 12,

Table 5. Average orthopyroxene compositions in Hole 923A gabbros.

\begin{tabular}{|c|c|c|c|c|c|c|c|c|c|c|c|c|c|c|}
\hline $\begin{array}{l}\text { Core, section, } \\
\text { interval }(\mathrm{cm})\end{array}$ & $n$ & $\mathrm{SiO}_{2}$ & $\mathrm{TiO}_{2}$ & $\mathrm{Al}_{2} \mathrm{O}_{3}$ & $\mathrm{Cr}_{2} \mathrm{O}_{3}$ & $\mathrm{FeO}$ & $\mathrm{MnO}$ & $\mathrm{MgO}$ & $\mathrm{CaO}$ & $\mathrm{Na}_{2} \mathrm{O}$ & $\mathrm{NiO}$ & Total & $\mathrm{Mg} \#$ & 1 s.d. \\
\hline \multicolumn{15}{|l|}{$153-923 \mathrm{~A}-$} \\
\hline $2 \mathrm{R}-1,8-12$ & 7 & 53.07 & 0.44 & 1.05 & 0.00 & 21.72 & 0.59 & 22.10 & 1.95 & 0.05 & 0.00 & 100.97 & 64.5 & \pm 1.3 \\
\hline $3 R-1,138-141$ & 2 & 54.55 & 0.35 & 1.23 & 0.04 & 15.78 & 0.41 & 27.03 & 1.27 & 0.02 & 0.03 & 100.71 & & \pm 0.3 \\
\hline $4 \mathrm{R}-1,35-37$ & 5 & 53.06 & 0.41 & 1.12 & 0.01 & 21.70 & 0.57 & 22.02 & 1.59 & 0.03 & 0.00 & 100.51 & 64.4 & \pm 1.1 \\
\hline SR-3,0-6 & 3 & 53.37 & 0.47 & 1.38 & 0.02 & 17.77 & 0.42 & 24.92 & 1.87 & 0.04 & 0.00 & 100.26 & 71.4 & \pm 0.4 \\
\hline $8 \mathrm{R}-2,96-100$ & 2 & 54.50 & 0.32 & 1.29 & 0.02 & 16.35 & 0.41 & 26.61 & 1.11 & 0.03 & 0.02 & 100.66 & 74.4 & \pm 0.5 \\
\hline $10 \mathrm{R}-2,122-127$ & 2 & 54.38 & 0.23 & 1.21 & 0.01 & 16.05 & 0.40 & 27.20 & 0.91 & 0.02 & 0.03 & 100.44 & 75.1 & \pm 0.4 \\
\hline
\end{tabular}

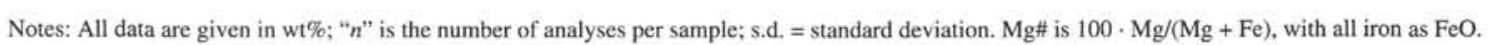


Table 6. Average oxide mineral compositions in Leg 153 gabbros.

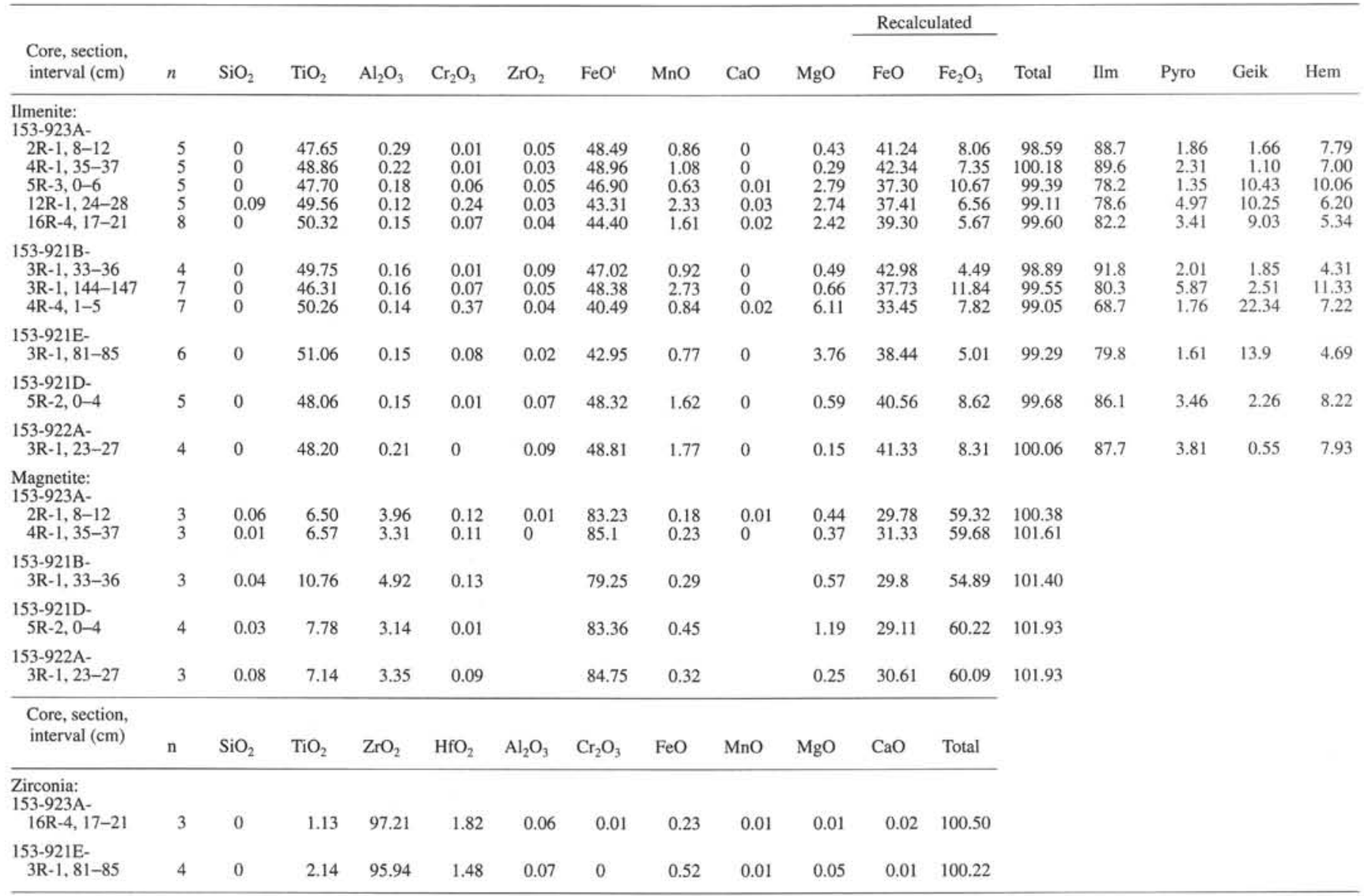

Notes: Data are given as wt\%; " $n$ " is the number of analyses per sample. Ilmenite analyses are recast into the following components: Ilm $=$ ilmenite $\left.(\mathrm{FeTiO})_{3}\right)$ Pyro $=$ pyrophanite $\left(\mathrm{MnTiO}_{3}\right)$, Geik = geikelite $\left(\mathrm{MgTiO}_{3}\right)$, and $\mathrm{Hem}=$ hematite $\left(\mathrm{Fe}_{2} \mathrm{O}_{3}\right)$. Iron is recalculated as $\mathrm{FeO}$ and $\mathrm{Fe}_{2} \mathrm{O}_{3}$ based on 3 oxygens per unit formula in ilmenite and 4 oxygens in magnetite.

Table 7. Average apatite compositions in Leg 153 gabbroic rocks.

\begin{tabular}{|c|c|c|c|c|c|c|c|c|c|c|c|c|c|c|c|c|c|c|}
\hline $\begin{array}{l}\text { Core, section, } \\
\text { interval }(\mathrm{cm})\end{array}$ & $n$ & $\mathrm{CaO}$ & $\mathrm{P}_{2} \mathrm{O5}$ & $\mathrm{F}$ & $\mathrm{Cl}$ & $\mathrm{SiO}_{2}$ & $\mathrm{MgO}$ & $\mathrm{SrO}$ & $\mathrm{Na}_{2} \mathrm{O}$ & $\mathrm{La}_{2} \mathrm{O}_{3}$ & $\mathrm{Ce}_{2} \mathrm{O}_{3}$ & $\mathrm{H}_{2} \mathrm{O}$ & Total & $\mathrm{O}(=\mathrm{F}, \mathrm{Cl})$ & Total & $\mathrm{X}(\mathrm{F})$ & $\mathrm{X}(\mathrm{Cl})$ & $\mathrm{X}(\mathrm{OH})$ \\
\hline \multicolumn{19}{|l|}{ 53-921D- } \\
\hline & 1 & 56.15 & 42.38 & 2.01 & 0 & 0.11 & 0.12 & 0.03 & 0.03 & 0 & 0.10 & 0.81 & 01.88 & 0.88 & 101.00 & 0.528 & 0.020 & 0.452 \\
\hline 1 & 5 & & & & & & & & & 0.01 & & & & & & & & 0.627 \\
\hline 1 & 5 & 55.79 & 42 & 2.0 & & & 0. & & & & & & & & 100 & & & 0.444 \\
\hline $5 \mathrm{R}-2,0$ & 5 & 55.21 & 42.22 & 2.17 & 0.04 & 0.19 & 0.09 & 0.02 & 0.06 & 0.03 & 0.12 & 0.75 & 100.89 & 0.9 & 99.97 & 0.574 & .005 & 0.421 \\
\hline \multicolumn{19}{|l|}{ 153-921B- } \\
\hline & 4 & 55.93 & 41 & 2.14 & 0.06 & 0.13 & 0.06 & 0.02 & 0.03 & 0.01 & 0.10 & 0.77 & 10 & 0. & 10 & 05 & 8 & 0.432 \\
\hline $4 \mathrm{~F}$ & 5 & 55.61 & 42. & 1.32 & 0.5 & 0.1 & 0.0 & 0.01 & 0.0 & 0.01 & 0.0 & 1.03 & 100.94 & 0.6 & 100.27 & 0.349 & 0.075 & 0.576 \\
\hline \multicolumn{19}{|l|}{$153-923 \mathrm{~A}$} \\
\hline & 3 & 56.15 & 42. & 1.76 & 0. & 0.08 & & 0.01 & & 0.03 & & 0.92 & & & & & & 6 \\
\hline & 5 & 55. & & 2. & & & & & & & & & & & & & & 0.435 \\
\hline & 4 & 55 & & 1. & & & & & & & & & & & & & & 0.496 \\
\hline $16 R-4,17-21$ & 5 & 55.39 & 42.18 & 2.18 & 0.13 & 0.21 & 0.08 & 0.01 & 0.05 & 0.02 & 0.14 & 0.72 & 101.10 & 0.95 & 100.16 & 0.576 & 0.018 & 0.405 \\
\hline \multicolumn{19}{|l|}{$153-922 \mathrm{~A}-$} \\
\hline $2 \mathrm{R}-5,1$ & 5 & 55.4 & 4 & 1.3 & 0.4 & 0.2 & 0. & 0.0 & 0. & 0.02 & 0. & 1.0 & & 0.6 & 100.28 & 0.362 & 0.057 & 0.581 \\
\hline $3 \mathrm{R}-1$ & 6 & 55.24 & 41.94 & 1.27 & 0.77 & 0.19 & 0.04 & 0.03 & 0.06 & 0.03 & 0.11 & 0.98 & 100.66 & 0.71 & 99.95 & 0.337 & 0.110 & 0.553 \\
\hline \multicolumn{19}{|l|}{ 153-922B- } \\
\hline
\end{tabular}

Notes: All data are given in wt $\%$; " $n$ " is the number of analyses per sample. $\mathrm{H}_{2} \mathrm{O}$ was calculated assuming $\mathrm{F}+\mathrm{Cl}+\mathrm{OH}=1$ per formula. $\mathrm{O}(=\mathrm{F}, \mathrm{Cl})$ is the amount of oxygen subtracted from the total resulting from $\mathrm{F}, \mathrm{Cl}$ balancing cation positive charges.

one, referred to as the "depleted series", had $\mathrm{La}_{n}$ of 1.5 to $3.5 \times$ chondrite, and the second melt, referred to as the "main series" gabbro parent, had 11 to $13 \times$ chondrite at $\mathrm{La}$. These relationships are displayed in Figure 10, which shows estimated main series and depleted series parental magmas and Kane basalts (data from Bryan et al., 1981). Large differences in REEs, $\mathrm{Zr}, \mathrm{Y}, \mathrm{Hf}$, and $(\mathrm{La} / \mathrm{Sm})_{n}$ are noted be- tween these two magma series, but they appear to have only minor differences in contents of $\mathrm{Na}, \mathrm{Sr}$, and Ti. Samples 153-923A-12R-1, $24-28 \mathrm{~cm}$, and $11 \mathrm{R}-2,129-135 \mathrm{~cm}$, crystallized from a melt substantially more depleted in incompatible trace elements than did most other gabbros in the Site 923 suite. There is a close match between our estimates of the parent of the main series gabbros and the erupted 
Table 8. INAA data for clinopyroxene mineral separates.

\begin{tabular}{|c|c|c|c|c|c|c|c|c|c|c|c|c|c|c|c|c|}
\hline $\begin{array}{l}\text { Core, section, } \\
\text { interval }(\mathrm{cm})\end{array}$ & $\mathrm{Na}_{2} \mathrm{O}$ & $\mathrm{CaO}$ & $\mathrm{FeO}$ & Sc & $\mathrm{Cr}$ & Co & $\mathrm{Ni}$ & $\mathrm{La}$ & $\mathrm{Ce}$ & $\mathrm{Sm}$ & Eu & $\mathrm{Tb}$ & $\mathrm{Yb}$ & $\mathrm{Lu}$ & $\mathrm{Zr}$ & $\mathrm{Hf}$ \\
\hline \multicolumn{17}{|l|}{ 153-923A- } \\
\hline $3 \mathrm{R}-1,138-141$ & 0.463 & 19.2 & 7.64 & 105.7 & 886 & 41.5 & 84 & 0.535 & 3.1 & 2.05 & 0.661 & 0.67 & 2.42 & 0.34 & \multirow{10}{*}{150} & 0.92 \\
\hline $4 R-1,127-131$ & 0.487 & 18.6 & 8.84 & 105.3 & 387 & 44.5 & 140 & 1.25 & 6.3 & 3.66 & 0.801 & 1.03 & 3.80 & 0.56 & & 2.16 \\
\hline $5 R-3,0-6$ & 0.433 & 19.3 & 8.37 & 107.3 & 343 & 44.7 & 89 & 0.431 & 2.48 & 2.11 & 0.705 & 0.662 & 2.55 & 0.36 & & 0.86 \\
\hline $7 \mathrm{R}-2,34-40$ & 0.658 & 20.5 & 6.99 & 100.0 & 3760 & 32.0 & 190 & 1.29 & 9.9 & 5.10 & 0.885 & 1.45 & 5.54 & 0.80 & & 3.73 \\
\hline $8 R-1,61-65$ & 0.437 & 18.8 & 7.84 & 104.1 & 584 & 42.7 & 150 & 0.877 & 4.8 & 2.57 & 0.714 & 0.80 & 2.96 & 0.42 & & 1.43 \\
\hline $10 \mathrm{R}-2,122-127$ & 0.432 & $\begin{array}{l}10.0 \\
18.8\end{array}$ & 7.33 & 100.9 & 877 & 40.2 & 101 & 0.331 & 2.4 & 1.73 & 0.616 & 0.572 & 2.17 & 0.34 & & 0.70 \\
\hline IIR-2, $129-135$ & 0.379 & 19.9 & 4.48 & 83.3 & 7720 & 32.0 & 278 & 0.17 & & 0.99 & 0.388 & 0.287 & 1.19 & 0.17 & & 0.46 \\
\hline $12 \mathrm{R}-1,24-28$ & 0.355 & 20.5 & 4.09 & 87.1 & 7970 & 32.7 & 260 & 0.117 & & 0.96 & 0.367 & 0.302 & 1.18 & 0.15 & & 0.39 \\
\hline $15 \mathrm{R}-2,114-118$ & 0.443 & 20.6 & 5.35 & 92.6 & 5130 & 31.5 & 184 & 0.362 & 5.0 & 2.02 & 0.51 & 0.582 & 2.20 & 0.32 & & 1.16 \\
\hline $16 \mathrm{R}-4,17-21$ & 0.425 & 20.0 & 4.67 & 91.8 & 5360 & 32.1 & 241 & 0.268 & 2.3 & 1.33 & 0.455 & 0.46 & 1.47 & 0.21 & & 0.64 \\
\hline $\begin{array}{l}153-921 \mathrm{~A}- \\
2 \mathrm{R}-2,12-15\end{array}$ & 0.420 & 17.5 & 10.09 & 105.2 & 265 & 51.8 & 126 & 0.468 & \multirow[t]{3}{*}{2.7} & 2.19 & 0.72 & 0.75 & 2.91 & \multicolumn{2}{|l|}{0.40} & 0.91 \\
\hline $153-921 \mathrm{~B}$ & & & & & & & & & & & & & & & & \\
\hline $4 \mathrm{R}-3,90-96$ & 0.375 & 19.6 & 4.52 & 85.1 & 5120 & 32.8 & 214 & 0.263 & & 1.05 & 0.379 & 0.363 & 1.27 & 0.20 & & 0.49 \\
\hline
\end{tabular}

Notes: Analytical uncertainties are $1 \%-2 \%$ for $\mathrm{Na}, \mathrm{Fe}, \mathrm{Sc}, \mathrm{Cr}$, and $\mathrm{Co}, 3 \%-5 \%$ for $\mathrm{La}, \mathrm{Sm}, \mathrm{Yb}$, and $\mathrm{Lu}, 5 \%-10 \%$ for $\mathrm{Tb}, \mathrm{Eu}$, and $\mathrm{Hf}$, and $10 \%-25 \%$ for $\mathrm{Ce}, \mathrm{Ni}, \mathrm{Ca}$, and $\mathrm{Zr}$. $\mathrm{Na} \mathrm{a}_{2} \mathrm{O}, \mathrm{CaO}$, and $\mathrm{FeO}$ are in wt\%. Other elements are in $\mathrm{ppm}$.

Table 9. INAA data for plagioclase mineral separates.

\begin{tabular}{|c|c|c|c|c|c|c|c|c|c|c|c|c|c|c|c|c|c|}
\hline $\begin{array}{l}\text { Core, section, } \\
\text { interval }(\mathrm{cm})\end{array}$ & $\mathrm{Na}_{2} \mathrm{O}$ & $\mathrm{CaO}$ & $\mathrm{FeO}$ & $\mathrm{Sc}$ & $\mathrm{Cr}$ & $\mathrm{Co}$ & $\mathrm{Sr}$ & $\mathrm{La}$ & $\mathrm{Ce}$ & $\mathrm{Sm}$ & Eu & $\mathrm{Tb}$ & $\mathrm{Yb}$ & $\mathrm{Lu}$ & $\mathrm{Zr}$ & Hf & $\mathrm{Br}$ \\
\hline \multicolumn{18}{|l|}{$153-923 \mathrm{~A}-$} \\
\hline $3 \mathrm{R}-1,138-141$ & 4.92 & 11.5 & 0.458 & 0.157 & 1.2 & 0.96 & 287 & 0.70 & 1.40 & 0.101 & 0.507 & 0.009 & $<0.027$ & $<0.0032$ & $<11$ & \multirow{12}{*}{22.8} & 0.23 \\
\hline $4 \mathrm{R}-1,35-37$ & 6.08 & 9.9 & 0.363 & 0.282 & 1.6 & 3.28 & 292 & 1.35 & 3.91 & 0.76 & 1.415 & 0.122 & 0.206 & 0.0244 & $<18$ & & 0.25 \\
\hline $4 \mathrm{R}-1,127-131$ & 5.22 & 11.3 & 0.532 & 0.122 & 1.6 & 1.02 & 271 & 1.72 & 3.69 & 0.276 & 0.804 & 0.029 & 0.033 & 0.0052 & $<12$ & & \\
\hline $5 R-3,0-6$ & 4.95 & 11.2 & 0.591 & 0.121 & 0.8 & 1.13 & 283 & 0.417 & 1.17 & 0.132 & 0.367 & 0.013 & $<0.040$ & $<0.005$ & $<22$ & & 0.20 \\
\hline $7 R-2,34-40$ & 3.52 & 13.9 & 0.416 & 0.105 & 1.3 & 0.64 & 210 & 1.23 & 3.03 & 0.321 & 0.564 & 0.033 & 0.049 & 0.010 & $<5$ & & \\
\hline $8 \mathrm{R}-1,61-65$ & 4.65 & 11.9 & 0.517 & 0.120 & 0.8 & 0.88 & 283 & 0.957 & 2.31 & 0.172 & 0.539 & 0.015 & 0.020 & 0.0037 & $<6$ & & 0.20 \\
\hline $10 \mathrm{R}-2,122-127$ & 4.55 & 12.0 & 0.52 & 0.170 & 1.1 & 0.77 & 266 & 0.39 & 0.95 & 0.103 & 0.503 & 0.015 & $<0.06$ & $<0.006$ & $<19$ & & 0.44 \\
\hline IIR-2, $129-135$ & 2.86 & 13.8 & 0.694 & 0.326 & 11.5 & 1.38 & 206 & 0.379 & 1.01 & 0.123 & 0.382 & 0.013 & $<0.06$ & $<0.005$ & $<20$ & & 0.37 \\
\hline $12 \mathrm{R}-1,24-28^{*}$ & 3.32 & 13.8 & 0.666 & 0.341 & 5.2 & 1.07 & 236 & 0.448 & 1.05 & 0.145 & 0.412 & 0.040 & 1.023 & 0.201 & 1040 & & 0.37 \\
\hline $12 \mathrm{R}-1,115-120$ & 3.18 & 14.3 & 0.515 & 0.247 & 0.6 & 0.78 & 222 & 0.277 & 0.77 & 0.122 & 0.335 & 0.018 & 0.031 & 0.0031 & $<8$ & & 0.31 \\
\hline $15 \mathrm{R}-2,114-118$ & 3.39 & 13.7 & 0.419 & 0.146 & 2.4 & 0.76 & 229 & 0.417 & 1.17 & 0.132 & 0.367 & 0.013 & $<0.040$ & $<0.005$ & $<14$ & & 0.27 \\
\hline $16 \mathrm{R}-4,17-21$ & 3.59 & 13.9 & 0.465 & 0.186 & 1.8 & 0.94 & 217 & 0.37 & 0.90 & 0.136 & 0.401 & 0.013 & 0.024 & 0.0027 & & & 0.46 \\
\hline $\begin{array}{l}153-921 \mathrm{~A}- \\
2 \mathrm{R}-2,12-15\end{array}$ & 5.36 & 11.2 & 0.552 & 0.126 & 0.7 & 1.01 & 262 & 0.64 & 1.34 & 0.139 & 0.686 & 0.018 & $<0.04$ & $<0.005$ & $<7$ & & \\
\hline 153-921B- & & & & & & & & & & & & & & & & & \\
\hline $4 \mathrm{R}-3,90-96$ & 3.2 & 14.1 & 0.548 & 0.173 & 2.8 & 1.12 & 247 & 0.488 & 1.27 & 0.154 & 0.389 & 0.018 & 0.031 & $<0.007$ & $<15$ & & 0.32 \\
\hline
\end{tabular}

Notes: * This plagioclase separate is contaminated with a $\mathrm{Zr}$-rich phase that appears to have concentrated heavy rare-earth elements. Analytical uncertainties are $1 \%-2 \%$ for $\mathrm{Na}$, Fe,

$\mathrm{Sc}, \mathrm{Cr}$, and $\mathrm{Co}, 3 \%-5 \%$ for $\mathrm{La}, \mathrm{Sm}$, and $\mathrm{Sr}, 5 \%$ for $\mathrm{Eu}$, and $15 \%-30 \%$ for $\mathrm{Ce}, \mathrm{Br}, \mathrm{Ca}, \mathrm{Tb}, \mathrm{Yb}, \mathrm{Lu}$, and $\mathrm{Zr}$. $\mathrm{Na} 2 \mathrm{O}, \mathrm{CaO}$, and $\mathrm{FeO}$ are in wt\%, other data are in $\mathrm{ppm}$.

Kane basalts, but the depleted series are notably lower in several incompatible elements relative to the erupted basalts. These two parental magmas cannot be related to one another by simple fractional crystallization. The abundances of incompatible trace elements in the main series melts were higher than would be produced by fractional crystallization of the depleted series.

Assignment of samples to the two different magma series depends on trace element contents in clinopyroxene. Examination of Hf abundances and REEs in clinopyroxene mineral separates (see Table 8) shows which samples crystallized from the depleted series, and which from the main series. Among the twelve samples for which we have clinopyroxene separate data, four crystallized from the depleted series (Samples 153-923A-12R-1, 24-28 cm, 11R-2, 129-135 cm, 16R-4, 17-21 cm, and 921B-4R3, 90-96 cm), six samples crystallized from the main series, and two are much more enriched and appear to have been affected by postcumulus processes. The different parental magmas that we have inferred for this suite are not apparent from looking at plagioclase REE abundances or from the whole-rock trace-element data. In Figure 11, Sm in clinopyroxene is plotted vs. $\mathrm{FeO}$ in clinopyroxene. Samples near $1 \mathrm{ppm} \mathrm{Sm}$ formed from the depleted series, those with $\mathrm{Sm}$ at $2-2.5 \mathrm{ppm}$ formed from the main series, and those with higher abundances are strongly enriched, probably because of trapped interstitial melt. Shown for comparison are Sm abundances in clinopyroxene separates from Site 334 cumulates (Ross, 1994). The Site 334 suite crystallized from strongly depleted MORB, formed by extensive fractional melting of the mantle. The nearly horizontal trend defined by 334 samples is typical of a trend expected from fractional crystallization. The great scatter in samples from Leg 153 results from both variable parental melts and postcumulus enrichments.

The four samples that clearly formed from the depleted parental melt are all poikilitic olivine gabbros with magnesian clinopyroxene (mean $\mathrm{Mg} \#$ ranges from 87.1 to 83.4). The main series samples for which we have trace-element data in clinopyroxene include both olivine gabbros and poikilitic olivine gabbros (Sample 153-923A-15R$2,114-118 \mathrm{~cm})$. Clinopyroxene mineral separates from the main series have $\mathrm{Mg} \#$ that varies from 83.5 to 77.0 . The parental magma of any particular sample in this suite cannot be determined on the basis of texture alone nor on the basis of bulk-rock trace-element composition. Our data set for other poikilitic olivine gabbros with magnesian clinopyroxene $(\mathrm{Mg \#}>84)$ at Site 921 does not permit evaluation of the character of the parental magma, because we do not have traceelement data in clinopyroxene for these rocks and the two magma series are not clearly distinguishable based on $\mathrm{Na}$ or $\mathrm{Ti}$ in clinopyroxene (elements that can be measured accurately by electron probe). At this stage, we cannot say whether all of the magnesian clinopyroxene-bearing samples crystallized from the depleted series or not.

Figure 12 shows $\mathrm{Sr}$ abundances in plagioclase separates from Leg 153 gabbroic rocks and at Site 334. Both suites formed from magmas with similar initial $\mathrm{Fe} / \mathrm{Mg}$ because the most primitive clinopyroxene in both suites have $\mathrm{Mg} \#$ of 88 . These cumulus minerals preserve geochemical differences that are a function of the differences in the 
Table 10. INAA data for Leg 153 gabbroic whole rocks.

\begin{tabular}{|c|c|c|c|c|c|c|c|c|c|c|c|c|c|c|c|c|c|}
\hline $\begin{array}{l}\text { Core, section, } \\
\text { interval }(\mathrm{cm})\end{array}$ & $\mathrm{Na}_{2} \mathrm{O}$ & $\mathrm{CaO}$ & $\mathrm{FeO}$ & Sc & $\mathrm{Cr}$ & Co & $\mathrm{Ni}$ & $\mathrm{Sr}$ & $\mathrm{La}$ & $\mathrm{Ce}$ & Sm & Eu & $\mathrm{Tb}$ & $\mathrm{Yb}$ & $\mathrm{Lu}$ & $\mathrm{Zr}$ & $\mathrm{Hf}$ \\
\hline \multicolumn{18}{|l|}{$153-923 \mathrm{~A}-$} \\
\hline $2 \mathrm{R}-1,8-12$ & 2.63 & 10.5 & 16.35 & 53.7 & 58.4 & 48.2 & $<52$ & 132 & 1.00 & 3.8 & 2.48 & 1.22 & 0.762 & 2.64 & 0.383 & 94 & 2.68 \\
\hline $3 \mathrm{R}-1,138-141$ & 2.37 & 15.2 & 5.58 & 54.7 & 426 & 38.4 & 120 & 151 & 0.60 & 2.16 & 1.23 & 0.583 & 0.355 & 1.38 & 0.194 & & 0.71 \\
\hline $4 \mathrm{R}-1,35-37$ & 2.93 & 9.8 & 12.35 & 44.8 & 53.3 & 56.1 & 63 & 160 & 0.86 & 3.02 & 1.93 & 1.109 & 0.59 & 2.26 & 0.335 & 44 & 1.68 \\
\hline $4 \mathrm{R}-1,127-131$ & 2.98 & 12.4 & 6.78 & 36.2 & 170.9 & 40.7 & 120 & 160 & $\begin{array}{l}.00 \\
1.58\end{array}$ & 5.11 & 1.82 & 0.79 & 0.477 & 1.72 & 0.257 & 90 & 1.20 \\
\hline $5 \mathrm{R}-1,58-63$ & 3.35 & 11.8 & 5.09 & 23.1 & 94.3 & 35.4 & 125 & 164 & 0.40 & 1.2 & 0.539 & 0.491 & 0.161 & 0.563 & 0.083 & & 0.29 \\
\hline $5 R-2,0-5$ & 2.92 & 12.5 & 6.18 & 40.4 & 135.9 & 39.6 & 120 & $\begin{array}{l}104 \\
122\end{array}$ & $\begin{array}{l}.40 \\
1.39\end{array}$ & 4.59 & 1.526 & 0.807 & 0.42 & 1.57 & 0.220 & & 0.96 \\
\hline $5 R-3,0-6$ & 2.96 & 13.0 & 6.12 & 36.3 & 148.3 & 39.7 & 119 & 186 & 0.44 & 1.68 & 0.855 & 0.551 & 0.259 & 0.99 & 0.137 & & 0.44 \\
\hline $6 \mathrm{R}-2,18-23$ & 2.31 & 13.8 & 5.96 & 45.7 & 455 & 42.6 & 146 & 137 & 0.40 & 1.43 & 0.919 & 0.53 & 0.273 & 1.08 & 0.149 & & 0.49 \\
\hline $7 \mathrm{R}-2,34-40$ & 3.01 & 12.5 & 4.00 & 13.2 & 159.1 & 30.1 & 197 & 216 & 1.67 & 5.32 & 1.51 & 0.755 & 0.345 & 1.28 & 0.182 & 35 & 1.14 \\
\hline $8 \mathrm{R}-1,61-65$ & 2.62 & 13.7 & 5.84 & 37.9 & 258 & 43.1 & 178 & 156 & 0.98 & 3.23 & 1.238 & 0.585 & 0.325 & 1.26 & 0.178 & & 0.85 \\
\hline $8 \mathrm{R}-2,96-100$ & 2.76 & 13.0 & 5.64 & 34.4 & 246 & 38.3 & 118 & 155 & 0.35 & 1.28 & 0.739 & 0.488 & 0.232 & 0.80 & 0.121 & & 0.35 \\
\hline $9 \mathrm{R}-1,135-141$ & 2.71 & 14.1 & 4.59 & 39.9 & 315 & 31.7 & 98 & 182 & 0.63 & 2.44 & 1.155 & 0.587 & 0.331 & 1.195 & 0.185 & & 0.59 \\
\hline $9 \mathrm{R}-3,10-15$ & 2.76 & 13.8 & 5.34 & 41.3 & 277 & 31.9 & 95 & 183 & 0.50 & 1.86 & 0.972 & 0.59 & 0.297 & 1.15 & 0.161 & & 0.47 \\
\hline $10 \mathrm{R}-2,122-127$ & 2.92 & 13.5 & 5.06 & 32.7 & 253 & 33.5 & 105 & 182 & 0.40 & 1.47 & 0.726 & 0.524 & 0.201 & 0.80 & 0.118 & & 0.32 \\
\hline $11 R-2,129-135$ & 0.96 & 10.8 & 7.15 & 33.5 & 2376 & 73.1 & 788 & 140 & 0.29 & 1.18 & 0.666 & 0.301 & 0.203 & 0.75 & 0.109 & & 0.39 \\
\hline $12 \mathrm{R}-1,24-28$ & 2.22 & 14.6 & 4.83 & 35.5 & 1979 & 36.0 & 192 & 141 & 0.55 & 2.12 & 0.937 & 0.504 & 0.279 & 0.91 & 0.136 & & 0.48 \\
\hline $12 \mathrm{R}-1,115-120$ & 2.17 & 11.2 & 4.78 & 10.1 & 121.5 & 43.7 & 325 & $\begin{array}{l}181 \\
182\end{array}$ & 0.26 & 0.76 & 0.297 & 0.284 & 0.075 & 0.288 & 0.043 & $<46$ & 0.15 \\
\hline $13 \mathrm{R}-1,65-69$ & 2.55 & 12.5 & 6.04 & 33.3 & 938 & 42.3 & 127 & 156 & 0.44 & 1.3 & 0.815 & 0.538 & 0.263 & 0.95 & 0.126 & & 0.40 \\
\hline $14 \mathrm{R}-1,36-40$ & 3.36 & 12.4 & 3.23 & 8.6 & 62 & 26.9 & $\begin{array}{l}169 \\
169\end{array}$ & 190 & 0.61 & 1.84 & 0.584 & 0.503 & 0.133 & 0.508 & 0.068 & 29 & 0.37 \\
\hline $15 \mathrm{R}-2,114-118$ & 2.44 & 12.1 & 4.11 & 13.3 & 510 & 40.1 & 255 & $\begin{array}{l}169 \\
169\end{array}$ & 0.41 & 1.23 & 0.494 & 0.351 & 0.112 & 0.431 & 0.064 & & 0.39 \\
\hline $15 R-3,21-25$ & 2.40 & 12.2 & 4.16 & 14.5 & 648 & 33.0 & 232 & 155 & 0.54 & 2.3 & 0.51 & 0.38 & 0.119 & 0.455 & 0.066 & & 0.26 \\
\hline $16 \mathrm{R}-3,5-$ & 2.22 & 9.1 & 6.30 & 8.5 & 59.2 & 54.9 & 400 & 136 & 0.54 & 1.77 & 0.582 & 0.375 & 0.144 & 0.565 & 0.081 & 30 & 0.48 \\
\hline $16 R-4,17-21$ & 2.43 & 11.0 & 4.93 & 16.6 & 558 & 39.6 & 276 & 96 & 0.56 & 1.95 & 0.647 & 0.401 & 0.193 & 0.64 & 0.091 & & 0.49 \\
\hline \multicolumn{18}{|l|}{$153-921 \mathrm{~A}-$} \\
\hline $2 \mathrm{R}-1,1$ & 3.14 & 13.0 & 5.97 & 47.0 & 137.6 & 31.3 & 71 & 164 & 0.513 & 1.74 & 1.123 & 0.708 & 0.34 & 1.35 & 0.202 & & 0.47 \\
\hline $2 \mathrm{R}-2,12-15$ & 2.81 & 13.0 & 7.29 & 46.5 & 143.9 & 41.1 & 94 & 123 & 0.461 & 1.89 & 1.10 & 0.688 & 0.333 & 1.33 & 0.197 & & 0.56 \\
\hline \multicolumn{18}{|l|}{ 153-921B- } \\
\hline $2 \mathrm{R}-1,120-124$ & 3.16 & 11.7 & 5.92 & 31.3 & 118.3 & 35.3 & 87 & 156 & 2.20 & 7.33 & 2.22 & 0.863 & 0.52 & 1.85 & 0.266 & $<70$ & 1.30 \\
\hline $2 \mathrm{R}-2,89-93$ & 2.76 & 13.6 & 4.82 & 37.5 & 233.2 & 33.3 & 123 & 140 & 0.963 & 348 & 1.285 & 0.587 & 0.361 & 1.23 & 0.179 & & 0.78 \\
\hline $3 R-1,144-147$ & 3.01 & 11.7 & 6.08 & 32.7 & 90.4 & 43.1 & 143 & 164 & 0.396 & 1.48 & 0.679 & 0.495 & 0.225 & 0.825 & 0.113 & & 0.29 \\
\hline $71-75$ & 2.42 & 14.0 & 4.79 & 38.5 & 393 & 34.9 & 182 & 167 & 0.404 & 2.0 & 0.753 & 0.468 & 0.228 & 0.866 & 0.122 & & 0.36 \\
\hline $4 \mathrm{R}-1,52-57$ & 1.86 & 14.3 & 4.77 & 34.2 & 1911 & 37.2 & 284 & 120 & 0.399 & 2.15 & 0.667 & 0.388 & 0.185 & 0.735 & 0.098 & & 0.30 \\
\hline $4 R-2,25-30$ & 2.18 & 9.5 & 5.74 & 7.4 & 117.4 & 50.9 & 428 & 162 & 0.598 & 1.79 & 0.484 & 0.314 & 0.101 & 0.417 & 0.061 & & 0.40 \\
\hline $4 \mathrm{R}-2,122-126$ & 1.99 & 7.5 & 9.28 & 6.5 & 106.1 & 76 & 470 & 154 & 0.5 & 1.45 & 0.354 & 0.303 & 0.085 & 0.353 & 0.059 & & 0.31 \\
\hline $4 \mathrm{R}-3,90-96$ & 1.64 & 12.9 & 4.71 & 24.3 & 1567 & 41 & 338 & 162 & 0.317 & 1.9 & 0.428 & 0.31 & 0.12 & 0.48 & 0.07 & & 0.26 \\
\hline $4 R-4,1-5$ & 2.10 & 12.1 & 3.41 & 2.5 & 50.1 & 30.7 & 293 & 182 & 0.345 & 1.03 & 0.238 & 0.331 & 0.06 & 0.177 & 0.025 & & 0.12 \\
\hline \multicolumn{18}{|l|}{$153-921 \mathrm{C}-$} \\
\hline $2 \mathrm{R}-2,70$ & 1.90 & 12.8 & 5.95 & 32.2 & 157 & 44 & 29 & 139 & 0.8 & 3.3 & 1. & 0.514 & 03 & 1.13 & 0.1 & & 0.77 \\
\hline $3 \mathrm{R}-1,108-110$ & 1.88 & 12.2 & 7.3 & 28.4 & 1520 & 54.4 & 290 & 147 & 0.351 & 1.39 & 0.550 & 0.39 & 0.157 & 0.603 & 0.087 & & 0.32 \\
\hline \multicolumn{18}{|l|}{ 153-921D- } \\
\hline $2 \mathrm{R}-1,13-18$ & 2.44 & 12.8 & 7.27 & 47.2 & 261 & 39 & 140 & 170 & 0.71 & 2.67 & 1.3 & 0.66 & 0.396 & 1.61 & 0.237 & & 0.79 \\
\hline & & 10.4 & 6.34 & 32 & 89.1 & 30.2 & 60 & 179 & 0.6 & 1. & 0.944 & 0.758 & 0.28 & 1.27 & 0.198 & & 0.51 \\
\hline $5 \mathrm{R}-2,0-4$ & 2.39 & 13.4 & 10.36 & 38.5 & 716 & 41.2 & 157 & 156 & 2.84 & 11.8 & 4.34 & 1.38 & 1.03 & 2.65 & 0.374 & 49 & 1.04 \\
\hline \multicolumn{18}{|l|}{ 153-921E- } \\
\hline $2 \mathrm{R}-1,100$ & 2.17 & 14.1 & 7.2 & 53.3 & 327 & 46. & 183 & 94 & 0.96 & 4.0 & 1.6 & 0.661 & 0.47 & 1.81 & 0.250 & 40 & 0.97 \\
\hline $2 \mathrm{R}-2,8-12$ & 3.4 & 12.2 & 4.85 & 27 & 160.9 & 28 & 108 & 210 & 1. & 4. & 1. & 0.74 & 0.384 & 1.312 & 0.1 & 43 & 1.04 \\
\hline $3 \mathrm{R}-1,19-24$ & 2.9 & 11.3 & 9.04 & 47.2 & 143.9 & 49 & 83 & 104 & 9.32 & 24 & 3.11 & 1.02 & 0.685 & 2.93 & 0.437 & & 1.56 \\
\hline 3 & 1.9 & 13.9 & & 47.4 & 546 & 47 & 202 & 125 & 0.7 & & 1.04 & 0.493 & 0.29 & 1.16 & 0.165 & & 0.48 \\
\hline $19-24$ & 2. & & & 26 & 540 & 3 & 231 & 142 & 0.3 & 1.32 & 0.520 & 0.348 & 0.144 & 0.521 & 0.077 & & 0.29 \\
\hline $5 R-3,32-36$ & 2.4 & 14.1 & 3.7 & 29 & 702 & 27.5 & 168 & 163 & 0.503 & 1.81 & 0.632 & 0.408 & 0.171 & 0.645 & 0.094 & & 0.36 \\
\hline $6 \mathrm{R}-1,101-106$ & 1.79 & 10.6 & 5.53 & 19 & 514 & 53 & & 140 & 0.4 & & 0.5 & & 4 & 0.54 & 0.074 & & 0.42 \\
\hline & 1.99 & 13 & 6.36 & 43 & 1130 & 43 & 218 & 134 & 0.9 & 3. & 1.57 & 0.6 & 0.441 & 1.601 & 0.230 & 46 & 0.98 \\
\hline $7 R-4,68-72$ & 1.68 & 14.9 & 5.35 & $\begin{array}{l}43.0 \\
46.7\end{array}$ & 804 & 39.9 & 279 & 170 & 0.56 & 2.33 & 1.073 & 0.525 & 0.327 & 1.14 & 0.157 & 61 & 0.63 \\
\hline \multicolumn{18}{|l|}{$153-922 \mathrm{~A}-$} \\
\hline $2 \mathrm{R}-3,15-1$ & 1.4 & 7.6 & 11.6 & 11 & 117. & 64 & 52 & 143 & 2.2 & 7.7 & 2.5 & 0.78 & 0.558 & 1.90 & 0.28 & 56 & 1.16 \\
\hline & 2.7 & 12.1 & 12.7 & 44 & 17 & 43 & 1 & 138 & 10.5 & 37. & 13 & 3. & 3.24 & 10. & . & 60 & 2.65 \\
\hline $3 \mathrm{R}-1,23-27$ & 2.22 & 11.0 & 4.14 & 4.3 & 145.3 & 32.9 & 290 & 195 & 1.17 & 3.37 & 0.834 & 0.51 & 0.192 & 0.704 & 0.105 & $<49$ & 0.77 \\
\hline \multicolumn{18}{|l|}{$153-922 \mathrm{~B}-$} \\
\hline IW-1, 37-40 & 1.8 & 11.8 & 4.2 & 15. & 62 & 39 & 4 & 29 & 1. & 3.5 & 1.3 & 0.4 & 0.317 & 1.19 & 0.164 & & 0.82 \\
\hline & ? & . & 60 & 8.1 & I & & & 179 & 1.3 & 4 & 1.3 & 0.7 & 0.33 & 1.2 & 01 & 54 & 0.87 \\
\hline $2 \mathrm{R}-2,88-92$ & 4.06 & 10.6 & 9.61 & 26.5 & 73.6 & 29.7 & 153 & 223 & 16.84 & 61.3 & 21.52 & 5.3 & 4.5 & 11.32 & 1.535 & 164 & 4.12 \\
\hline
\end{tabular}

Notes: $\mathrm{Na}_{2} \mathrm{O}, \mathrm{CaO}$, and $\mathrm{FeO}$ are in wt \%. Other data are in ppm.

trace-element contents of their parental magmas. The complexity of cumulate rock solidification processes requires detailed study of their geochemistry to unravel effects related to parental melt compositional variations vs. those related to postcumulus crystallization, but the rocks do, in fact, record robust information about their parental melts. This point is also illustrated in Figure 13, where large differences in bulk-rock compositions between Leg 153 olivine gabbro and Site 334 olivine gabbronorites are a consequence of large differences in the compositions of their parental melts. Figures 3 and 5 also illustrate these differences based on differences in anorthite in plagioclase and $\mathrm{Na}_{2} \mathrm{O}$ in clinopyroxene.

Bulk-rock REE abundances, shown in Figures 9A-9G reflect modal variations, some differences in parental melts, and differences in amounts of trapped liquid or amounts of late-stage trace-elementenriched phases such as apatite and zirconia. The majority of these rocks, with $\mathrm{La}_{\mathrm{n}}$ less than $2 \times$ chondrite, are cumulates with small amounts of trapped intercumulus melt. Actual whole-rock REE abundances in Hole 923A samples, when compared to model REE abundances, calculated using measured REEs in clinopyroxene and plagioclase, model REEs in olivine and modes (see Table 1), show enrichments that are due to trapped melt and/or due to the deposition from intercumulus melts of trace-element-enriched late-stage phases. We have constructed a series of models attempting to quantify the abundances of trapped melt in these samples, using various estimates of the abundances of REEs in melt. These models suggest that these samples contain from near $0 \%$ up to $30 \%$ trapped melt (readers may 


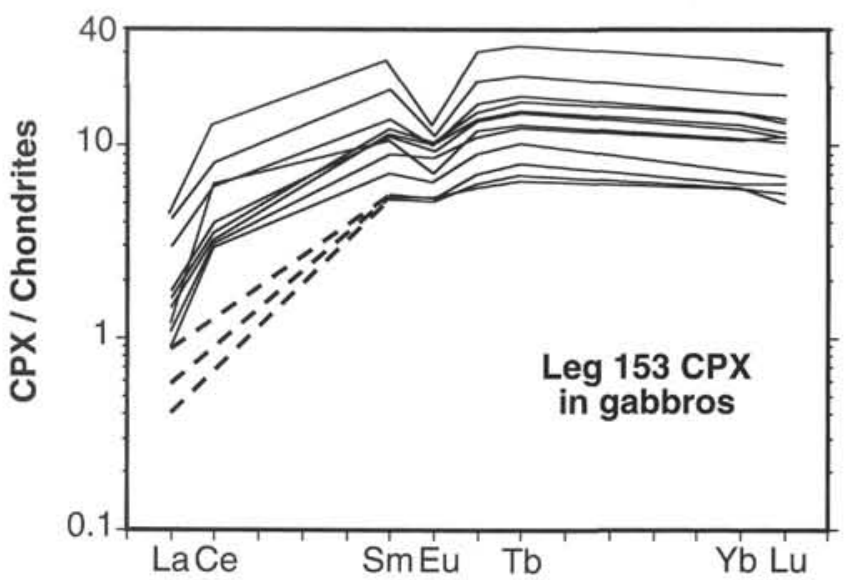

Figure 7. Chondrite-normalized REE patterns of clinopyroxene (CPX) mineral separates from Leg 153 gabbroic rocks. Two samples are from Holes $921 \mathrm{~A}$ and $921 \mathrm{~B}$, the remaining samples were separated from Hole 923A rocks. Data are normalized to chondrite values of Anders and Ebihara (1982) multiplied by 1.27 , as are all normalized REE data that appear in the figures that follow

obtain the results of trapped melt and modal abundance models by writing to K. R.). None of the models results in good fits for all measured REEs. Calculating amounts of trapped melt needed to balance the observed whole-rock REE abundances leads to the surprising result that trapping melt in quantities sufficient to balance $\mathrm{La}$ in the whole rock leaves large deficiencies in the model-rock heavy REEs (HREEs) for most samples. Models in which we minimized the summed deviations for REEs result in La in model whole rocks that exceeds the measured abundances well beyond analytical uncertainties. The amount of trapped melt calculated by balancing $\mathrm{La}$ is, in most samples, $<5 \%$. It is possible that the incompatible trace-element-enriched material added to the cumulus grains in these rocks was not simply a trapped melt, but was in fact enriched in HREEs relative to the melt.

One possible solution to this problem is suggested by data on an impure plagioclase separate from Sample 153-923A-12R-1, 24-28 $\mathrm{cm}$ (see Table 9). This separate has $1040 \mathrm{ppm} \mathrm{Zr}$ and $22.8 \mathrm{ppm} \mathrm{Hf}$. All other plagioclase separates have $<20 \mathrm{ppm} \mathrm{Zr}$ and $\mathrm{Hf}$ below detection limits. Clearly, this separate was contaminated with a high- $\mathrm{Zr}$ phase, and $\ll<1 \%$ contamination of a $\mathrm{Zr}$-rich phase could easily account for the high $\mathrm{Zr}$ in the separate. HREE abundances in this separate are 1 to 2 orders of magnitude greater than in other plagioclase separates. It seems likely that baddeleyite is the contaminant in this mineral separate. Zircon concentrates HREEs $\left(\mathrm{D}_{\mathrm{Zz}}\right.$ for zircon/liquid is 100 to 1000; Nagasawa, 1970) and, although no data are available on rare-earth partitioning in baddeleyite, it seems likely that it concentrates the HREEs, like zircon. Baddeleyite has been observed in 11 of 55 samples that were investigated in this study and it is possible that this phase is responsible for the HREE enrichments in whole-rock samples from this suite.

Most Leg 153 gabbroic rocks are clearly cumulates because their $\mathrm{Mg} \#$ exceeds 75, which is higher than the most primitive mantle derived melts, indicating that they have accumulated magnesian mafic phases. The positive europium anomalies observed in most of these rocks indicate that they are also plagioclase cumulates. Modeling of europium anomalies in those rocks for which we have both clinopyroxene and plagioclase REE data shows that mixing these phases in their observed proportions would result in bulk-rock Eu anomalies of 1.3 to 2.7. Actual Eu anomalies in these rocks range from about 1.1 to 2.5. The bulk-rock inventory of $\mathrm{Sm}$ and $\mathrm{Tb}$ is dominated by clinopyroxene, and clinopyroxene has negative Eu anomalies, so that even though plagioclases in these rocks have Eu anomalies of 8-13, the expected Eu anomalies in the bulk rocks are much lower.

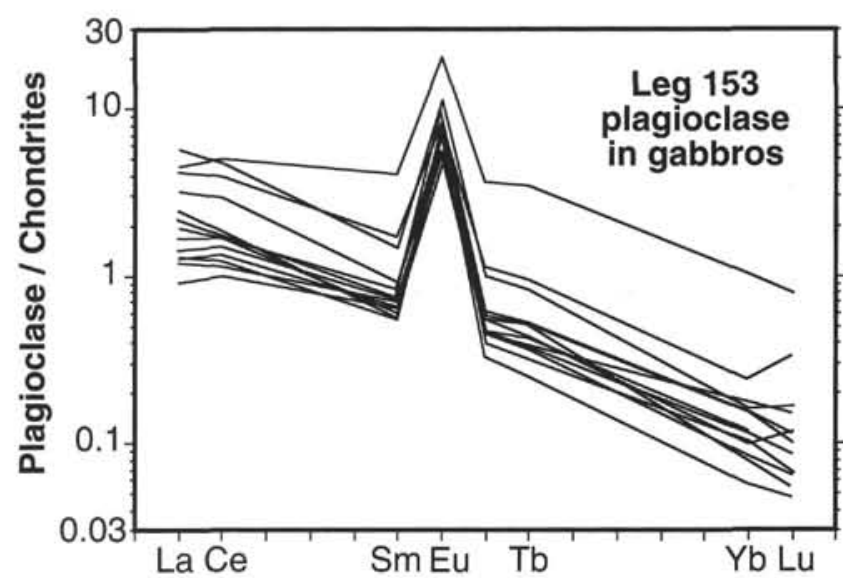

Figure 8 . Chondrite-normalized REE patterns of plagioclase mineral separates from Holes 923A, 921A, and 921B.

Trapped, evolved liquid, which has a negative Eu anomaly caused by separation of plagioclase, would account for the lower observed anomalies, as would deposition of apatite, which also has negative Eu anomalies. Some gabbroic rocks from Site 921 (see Figs. 9D-9G) have liquid-like abundances of REEs and no Eu anomalies and could represent liquid compositions, however, in samples for which we have obtained major-element data of mafic minerals, it is clear that these rocks are cumulate (Sample 153-921E-7R-2, 12-17 cm; Mg\# of clinopyroxene is 85.8).

Judging from the limited number of samples investigated in this work, and from shipboard X-ray fluorescence (XRF) data, Site 922 rocks are more enriched in trace elements than most rocks from other gabbroic sites. Petrographic observations and shipboard XRF data also showed greater quantities of oxides and late-stage apatite and zircon-bearing rocks at Site 922 . Those samples with unusually high REEs (see Figs. 9D, 9E, 9G), with $\mathrm{La}_{\mathrm{n}}$ at 10 to $60 \times$ chondrite, must be either late-stage cumulates with apatite as a cumulus phase, or must be essentially solidified, late-stage, very evolved melts.

Incompatible trace-element enrichments in Leg 153 gabbroic rocks are illustrated in Figure 14, which shows $\mathrm{Zr}$ vs. $\mathrm{P}_{2} \mathrm{O}_{5}$ (data in Cannat, Karson, Miller, et al., 1995; shipboard XRF) and in Figure 15 , which shows $\mathrm{Sr}$ vs. $\mathrm{Zr}$ in Leg 153 rocks. Both diagrams show gabbro data trending toward the field of Kane basalts. The most enriched gabbros have $\mathrm{Zr}$ abundances near that in Kane basaltic melts. Perfect cumulates from Leg 153 melts (i.e., adcumulates with no interstitial trapped melt or late-stage phases) would all fall near zero phosphorous and 5 to $15 \mathrm{ppm} \mathrm{Zr}$. The Leg 153 rocks have higher abundances of these elements than are expected in adcumulates because of the presence of trapped melt, apatite, $\mathrm{Zr}$-enriched rims or zones in clinopyroxene, $\mathrm{Zr}$-bearing ilmenite, and baddeleyite. The degree of crystallization required to saturate a primitive Kane glass in apatite is $>80 \%$ and is even higher for saturation in a zirconium-bearing phase. We have not observed the very albitic plagioclase or extremely ironrich mafic phases that would crystallize from magmas evolving toward saturation in these late-stage phases, and yet the presence of the late-stage phases appears to require that melt was trapped in the rocks, or that very evolved melt percolated through the rocks. Either percolating melts were buffered at relatively primitive major-element compositions by interaction with refractory cumulus phases, or traceelement-enriched, primitive melt produced by very low degrees of melting must have been involved in this system. One gabbro sample, Sample 153-923A-7R-2, 34-40 cm, has remarkably high abundances of $\mathrm{REE}$ and $\mathrm{Zr}$ (68-433 ppm Zr; see Table 11), and yet has $\mathrm{Mg \#}$ of 80 in clinopyroxene. Such high $\mathrm{Zr}$ in clinopyroxene is very difficult to explain as crystallizing from any MORB magma. Using the clinopyroxene/melt D of 0.12 (Hart and Dunn, 1993) implies that the melt that crystallized this sample had $\mathrm{Zr}$ abundances of 560 to 3500 

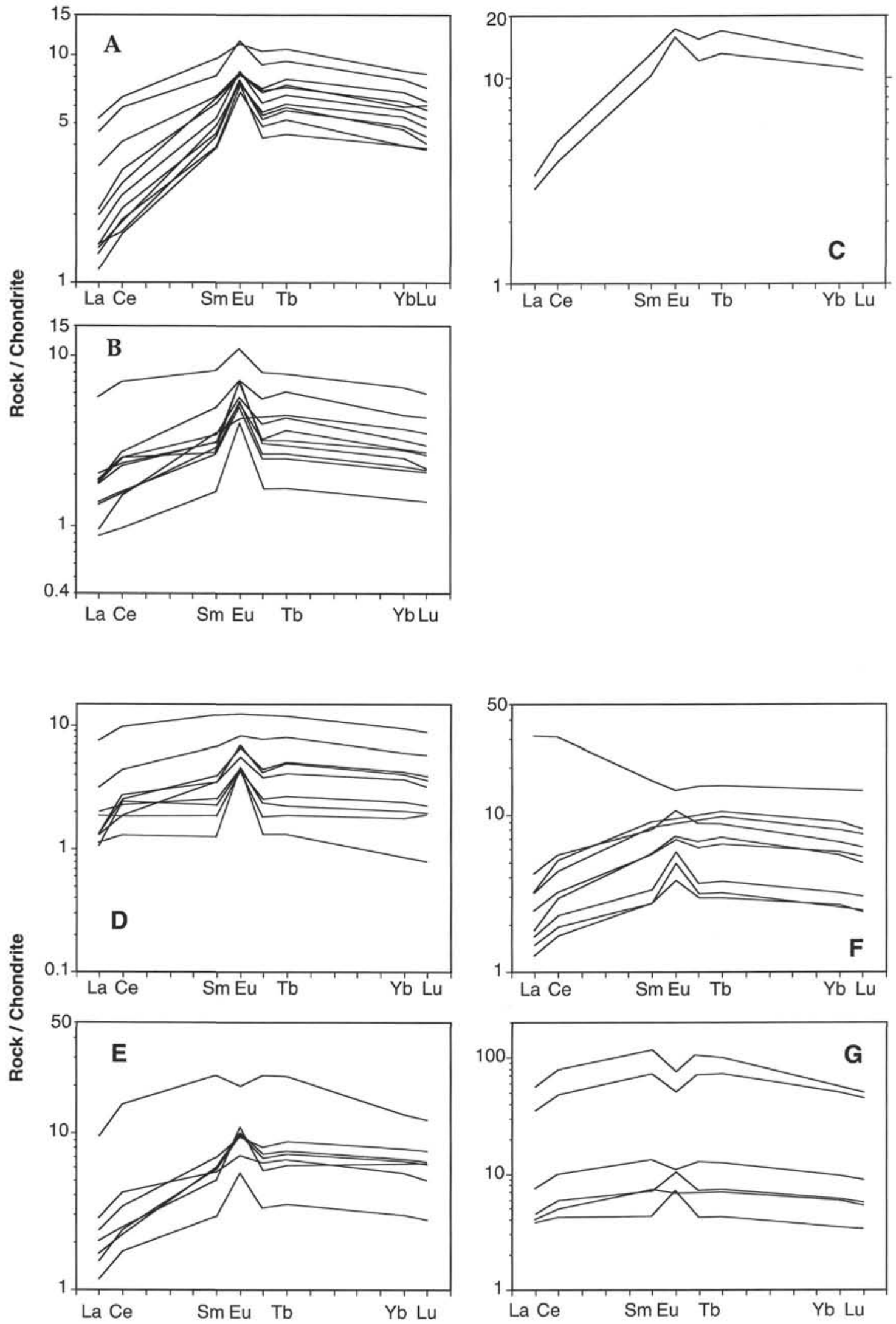

Figure 9. Chondrite-normalized REE patterns of whole-rock gabbros from Leg 153. A. Hole 923A olivine gabbro. B. Hole 923A poikilitic olivine gabbro. C. Hole 923A oxide gabbronorite. D. Gabbroic rocks from Hole 921B. E. Hole 921A, 921C, and 921D gabbroic rocks. F. Hole 921 E gabbroic rocks. G. Site 922 whole-rock REE patterns. 
Table 11. Ion probe data (in ppm) for clinopyroxene in gabbros.

\begin{tabular}{|c|c|c|c|c|c|c|c|c|c|c|c|c|c|c|c|}
\hline $\begin{array}{l}\text { Core, section, } \\
\text { interval }(\mathrm{cm})\end{array}$ & $\mathrm{Mg} \#$ & $\mathrm{La}$ & $\mathrm{Ce}$ & $\mathrm{Nd}$ & Sm & Eu & Dy & $\mathrm{Er}$ & $\mathrm{Yb}$ & $\mathrm{Ti}$ & $\mathrm{v}$ & $\mathrm{Cr}$ & $\mathrm{Sr}$ & $\mathrm{Y}$ & $\mathrm{Zr}$ \\
\hline \multicolumn{16}{|l|}{ 153-923A- } \\
\hline $12 \mathrm{R}-1,24-28 \mathrm{c}$ & 88.0 & 0.186 & 0.84 & 1.84 & 1.24 & 0.43 & 2.51 & 1.27 & 1.50 & 2204 & 233 & 7362 & 10.1 & 9.5 & 7.6 \\
\hline c & 88.2 & 0.104 & 0.65 & 1.38 & 0.95 & 0.41 & 1.82 & 1.18 & 1.16 & 2235 & 237 & 7206 & 11.0 & 9.6 & 6.9 \\
\hline c & & 0.109 & 0.65 & 1.72 & 1.01 & 0.50 & 2.11 & 1.18 & 1.25 & 1821 & 215 & 7440 & 4 & 7.9 & 4.9 \\
\hline c & 88.6 & 0.087 & 0.45 & 1.11 & 0.91 & 0.44 & 1.72 & 1.14 & 1.10 & & & & & & \\
\hline $\mathrm{r}$ & 85.8 & 0.152 & 0.87 & 2.01 & 1.23 & 0.53 & 2.58 & 1.88 & 1.93 & 2680 & 259 & 4844 & 9.5 & 14.9 & 14.2 \\
\hline $\mathrm{r}$ & 85.3 & 0.087 & 0.42 & 1.10 & 0.64 & 0.39 & 1.31 & 0.80 & 0.80 & 1777 & 223 & 7490 & & 8.9 & 5.1 \\
\hline $\mathrm{r}$ & & 0.047 & 0.32 & 1.05 & 0.70 & 0.39 & 1.20 & 1.00 & 0.79 & & & & & & \\
\hline \multicolumn{16}{|l|}{$153-923 \mathrm{~A}-$} \\
\hline $11 \mathrm{R}-2,129-135 \mathrm{c}$ & 88.1 & 0.216 & 1.00 & 1.96 & 1.16 & 0.57 & 2.33 & 1.15 & 1.32 & 2125 & 278 & 6780 & 11.9 & 10.6 & 9.0 \\
\hline c & & 0.166 & 0.93 & 1.82 & 1.21 & 0.51 & 2.42 & 1.33 & 1.39 & 1872 & 302 & 6716 & 11.4 & 12.4 & 14.0 \\
\hline c & & 0.114 & 0.80 & 1.70 & 0.97 & 0.44 & 2.02 & 1.21 & 1.26 & 2043 & 269 & 6899 & 10.9 & 10.6 & 9.4 \\
\hline $\mathbf{r}$ & 87.3 & 0.333 & 1.70 & 2.90 & 1.41 & 0.54 & 3.31 & 1.69 & 2.06 & 3999 & 334 & 5126 & 7.2 & 18.3 & 32.3 \\
\hline c & 88.1 & 0.137 & 0.75 & 1.67 & 0.94 & 0 & 2.14 & 1.10 & 1.32 & 2044 & 262 & 6477 & 10.3 & 10.5 & 10.0 \\
\hline $\mathrm{r}$ & 87.6 & 0.233 & 1.25 & 2.53 & 1.16 & 0.54 & 3.14 & 1.70 & 1.99 & & & & & & \\
\hline \multicolumn{16}{|l|}{$153-923 \mathrm{~A}-$} \\
\hline $15 \mathrm{R}-2,114-118 \mathrm{c}$ & 84.6 & 0.405 & 1.96 & 2.89 & 1.53 & 0.59 & 2.68 & 1.58 & 1.60 & 2767 & 312 & 8633 & 9.3 & 13.6 & 14 \\
\hline c & 84.9 & 0.319 & 1.88 & 3.09 & 1.40 & 0.49 & 2.59 & 1.45 & & 2266 & 235 & 6069 & 7. & 13.5 & 22 \\
\hline $\mathrm{r}$ & 84.5 & 0.45 & 2.64 & 4. & 2. & & 3. & 2. & 2.32 & 4107 & 321 & 6793 & 6 & 20.1 & 64 \\
\hline c & & 0.367 & 2.28 & 3.66 & 1.90 & 0. & 3.35 & 1.83 & 2.08 & 2163 & 295 & 1102 & 7.0 & 15.9 & 21 \\
\hline c & 83.6 & 0.524 & 3.13 & 5.11 & 2.49 & 0.68 & 4.27 & 2.62 & 2.87 & & & & & & \\
\hline \multicolumn{16}{|l|}{$153-923 \mathrm{~A}-$} \\
\hline $5 \mathrm{R}-1,58-63 \mathrm{c}$ & 79.9 & 0.389 & 1.73 & 2.9 & 1.4 & 0.70 & 3.33 & 1.9 & 2.05 & 3382 & 363 & 343 & 9.5 & 17.4 & 14 \\
\hline c & 80.8 & 0.410 & 2.16 & 3.3 & 1.8 & 0.65 & 3.46 & 2.17 & 2.36 & 3290 & 36 & 274 & 8.9 & 18.7 & 19 \\
\hline $\mathrm{r}$ & 78.4 & 0.5 & 3. & 5. & 2. & 0. & 5. & 2.87 & 2.90 & 4199 & 405 & 301 & 8.2 & 25.5 & 46 \\
\hline c & & 0.465 & 2.11 & 3.28 & 1.82 & 0.71 & 3.19 & 1.90 & 2.07 & & & & & & \\
\hline \multicolumn{16}{|l|}{$153-923 \mathrm{~A}-$} \\
\hline $7 \mathrm{R}-2$ & 79.8 & 1.96 & 11.33 & 18.12 & 9.5 & 1.17 & 15.32 & 8.11 & 9.92 & 6347 & 481 & 442 & 8.60 & 79.7 & 433 \\
\hline c & 80. & i. & 9.16 & 15. & & & 13. & 7. & & 5411 & 410 & 618 & 8.2 & 68.8 & 389 \\
\hline c & & 1.38 & 6.42 & 8.30 & 4.24 & 1.08 & 7.94 & 4.46 & 5.32 & 5701 & 470 & 630 & 8.6 & 35.1 & 68 \\
\hline c & 81.7 & 1.28 & 5.42 & 5.28 & 3.32 & 0.47 & 2.83 & 2.28 & 2.68 & & & & & & \\
\hline c & & & & & & & & & & 5918 & 439 & 675 & 8.1 & 68.3 & 281 \\
\hline 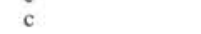 & & & & & & & & & & 5742 & 410 & 1316 & 7.8 & 76.5 & 389 \\
\hline
\end{tabular}

Notes: The letter "c" indicates core of grain, and " $\mathrm{r}$ " indicates rim. Typical relative errors at these abundance levels for $\mathrm{La}$ and $\mathrm{Ce}$ are $\pm 15 \%-20 \%$; $\mathrm{Zr}, \mathrm{Nd}, \mathrm{Sm}, \mathrm{Eu}, \mathrm{Er}$, and $\mathrm{Yb}$ are \pm $10 \% ; \mathrm{Ti}, \mathrm{V}, \mathrm{Cr}$ are $\pm 1 \%-2 \%$; and $\mathrm{Y}$ and $\mathrm{Sr}$ are $\pm 5 \%$.

Table 12. Inferred parental magmas of Hole 923A gabbros.

\begin{tabular}{lllll}
\hline & Kane basalt & $\begin{array}{c}\text { Main series } \\
\text { gabbro parent }\end{array}$ & $\begin{array}{c}\text { Depleted series } \\
\text { gabbro parent }\end{array}$ & $\begin{array}{c}\mathrm{D} \mathrm{cpx} / \text { liq } \\
\text { or pl/liq (Sr) }\end{array}$ \\
\hline $\mathrm{Mg \#}$ & $62-63$ & $56-58$ & $63-65$ & 0.27 \\
$\mathrm{Na}_{2} \mathrm{O}$ & $2.8-3.0$ & $2.9-3.6$ & $3.0-3.2$ & 0.12 \\
$\mathrm{TiO}_{2}$ & $1.1-1.5$ & $1.0-1.25$ & $0.8-0.95$ & 0.40 \\
$\mathrm{Sr}$ & $120-150$ & 140 & 120 & 2.0 \\
$\mathrm{Zr}$ & $90-120$ & 120 & $50-65$ & 0.12 \\
$\mathrm{Y}$ & $31-40$ & $30-36$ & $17-21$ & 0.48 \\
$\mathrm{Hf}$ & $2.2-2.6$ & $2.3-2.6$ & $1.5-1.8$ & 0.256 \\
$\mathrm{La}$ & $9.5-13$ & $11.0-13.0$ & $1.5-3.7$ & 0.095 \\
$\mathrm{Sm}_{n}$ & $17-19$ & $21-26$ & $10.0-15.0$ & 0.32 \\
$\mathrm{Yb}_{n}$ & $14-17$ & $20-25$ & $9.5-13$ & 0.40 \\
$(\mathrm{La} / \mathrm{Sm})_{n}$ & $0.56-0.72$ & $0.50-0.58$ & $0.17-0.30$ & 0.30 \\
\hline
\end{tabular}

Notes: $\mathrm{Mg} \#$ is $100 \cdot \mathrm{Mg} /(\mathrm{Mg}+\mathrm{Fe})$, in molar units. $\mathrm{Na}_{2} \mathrm{O}$ and $\mathrm{TiO}$, are in wt\%. $\mathrm{Sr}, \mathrm{Zr}, \mathrm{Y}$, and $\mathrm{Hf}$ are in ppm. REEs are normalized to chondritic values from Anders and Ebihara (1982) multiplied by 1.27. Estimated parental melts are calculated by using the depleted subset of ion probe clinopyroxene analyses from Sample 153-923A-12R. 1, 24-28 cm, for the depleted series parent, and from Samples 153-923A-5R-1, 58$63 \mathrm{~cm}$, and $15 \mathrm{R}-2,114-118 \mathrm{~cm}$, for the main series parent. Electron probe data for these samples were used to derive estimates of parental melts for $\mathrm{Na}_{2} \mathrm{O}$ and $\mathrm{TiO}_{2}$. See text for further discussion; $\mathrm{pl}=$ plagioclase, liq = liquid, $\mathrm{cpx}=$ clinopyroxene.

ppm $\mathrm{Zr}$, while crystallizing clinopyroxene with $\mathrm{Mg} \#$ 80. Titanium oxide contents in clinopyroxene in this sample are uniformly high, rather than extending from the low values typical of most of the suite. This sample also falls well off the trend in Figure 5 ( $\mathrm{Mg \#}$ vs. $\mathrm{Na}_{2} \mathrm{O}$ in clinopyroxene) observed in the rest of the suite. Perhaps such a remarkably enriched melt, percolating through cumulates formed from more conventional magmas, could explain the presence of baddeleyite in so many of these rocks, and the presence of apatite in rocks with limited major-element variations in mineral compositions.

\section{DISCUSSION}

Both Kane erupted lavas and the Leg 153 gabbroic rocks under investigation here show features that are inconsistent with crystalliza-

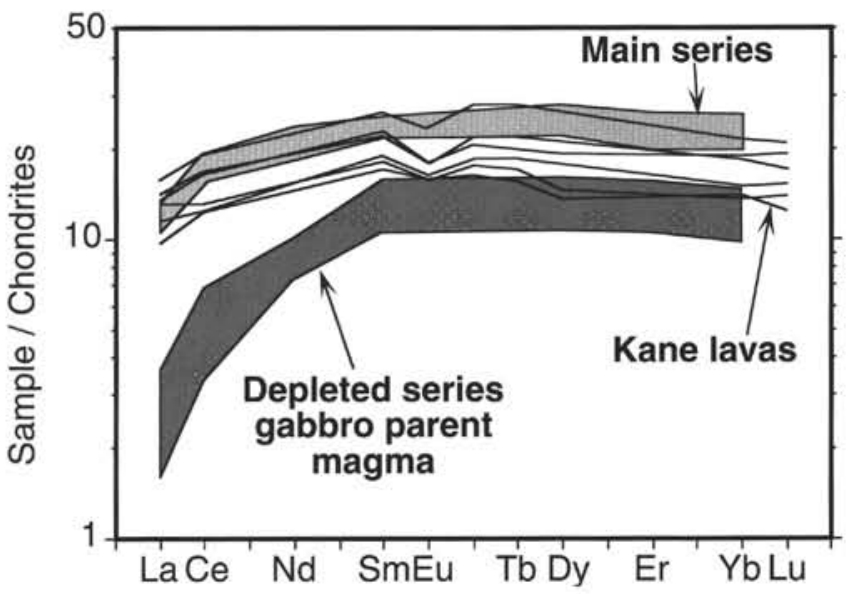

Figure 10. REE field of model liquids in equilibrium with clinopyroxene from Leg 153 gabbros (calculated using the clinopyroxene/liquid distribution coefficients from Grutzeck et al., 1974) and REE patterns of erupted Kane lavas (data from Bryan et al., 1981).

tion at the low pressures that would apply in crustal level magma chambers. In the gabbroic rocks, evidence that is inconsistent with low-pressure crystallization consists of the high $\mathrm{Mg \#}$ of clinopyroxene. Several experimental studies of Kane lavas (Tormey et al., 1987; Grove et al., 1990,1992) have shown that at $1 \mathrm{~atm}$, Kane melts will begin to crystallize clinopyroxene at Mg\# 82-83. In Leg 153 gabbros from Site 923 and 921 , many samples contain clinopyroxene with $\mathrm{Mg} \#$ ranging from 88 to 86 . Modeling of crystallization of a primitive Kane lava using the MIXNFRAC program of Nielsen (1988) shows that crystallization produces initial clinopyroxene with $\mathrm{Mg \#}$ of 82 , when $\mathrm{MgO}$ in the melt is at $6.2 \mathrm{wt} \%$. In experiments on Kane Fracture Zone basalts (Tormey et al., 1987; Grove et al., 1990, 1992) clinopyroxene joins the crystallizing assemblage at 6.5 to $6.7 \mathrm{wt} \%$ 


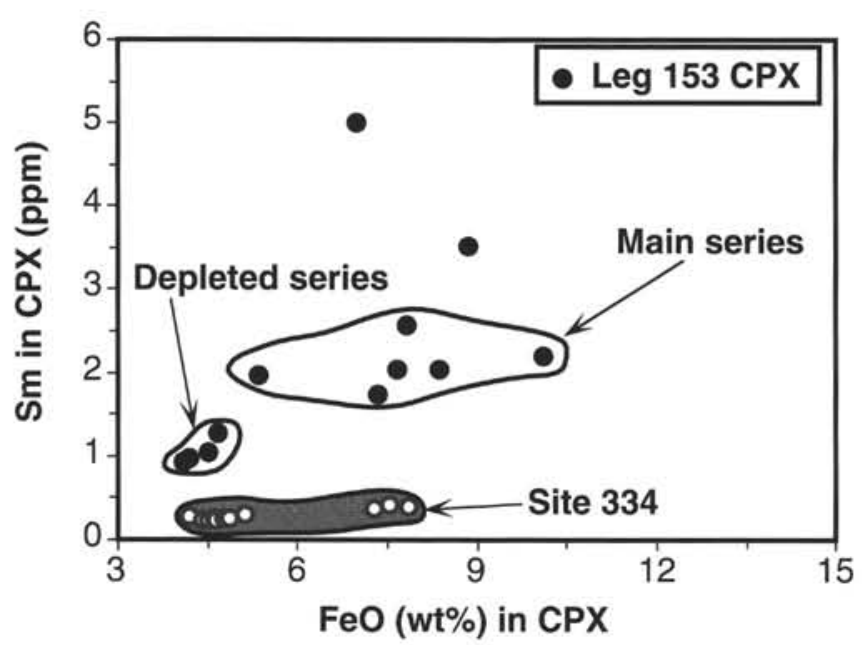

Figure 11. Sm (in ppm) in clinopyroxene vs. $\mathrm{FeO}(\mathrm{wt} \%$ ) in clinopyroxene (CPX) in mineral separates from Leg 153 (determined by INAA). Samples that are believed to have crystallized from main series and depleted series magmas are shown encircled. Two samples with much higher abundances of Sm probably crystallized from main series magmas, but are enriched in REE because of melt trapping. Shown for comparison are data from Site 334 ultramafic and gabbroic cumulates (Ross, 1994). Fractional crystallization produces a nearly horizontal trend on this plot. The extreme variability in Leg 153 gabbroic rocks suggests variable parental magmas and trace-element enrichments resulting from crystallization of intercumulus liquid.

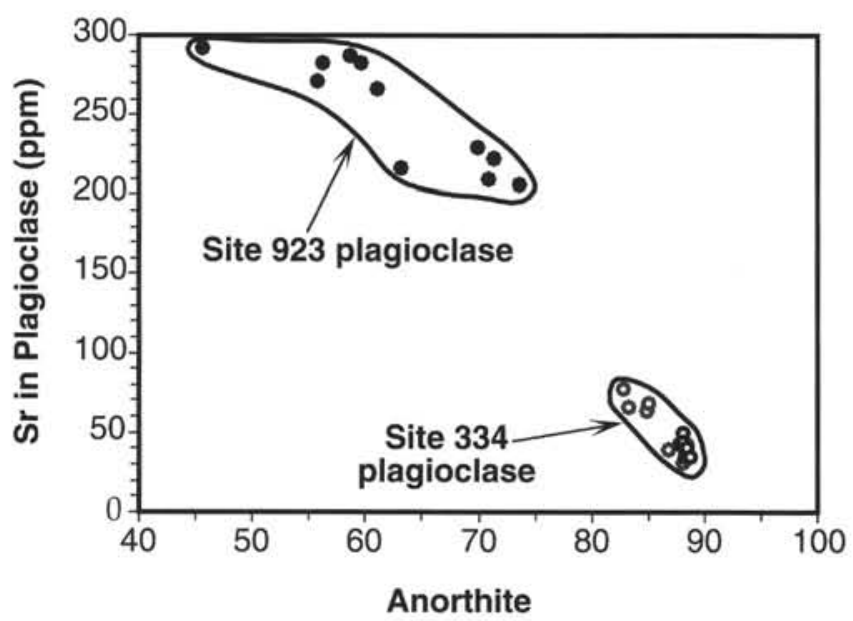

Figure 12. Sr in plagioclase (INAA data) vs. An in plagioclase (from electron probe data). Site 334 data are from Ross (1994). Both data sets come from sample suites where the $\mathrm{Mg} \#$ of clinopyroxene ranges from 88 to 70 . Cumulate rocks record primary magmatic geochemical differences that result from different parental magma compositions. Leg 153 gabbros crystallized from relatively enriched $\mathrm{N}-\mathrm{MORB}$, and Site 334 cumulates crystallized from strongly depleted MORB.

$\mathrm{MgO}$. In Figure $16, \mathrm{MgO}$ vs. $\mathrm{CaO}$ in Kane glasses is shown. The model liquid line of descent predicted by Nielsen's program is shown by the curve for perfect fractional crystallization. The onset of clinopyroxene crystallization occurs at the inflection in this curve at approximately $6.2 \mathrm{wt} \% \mathrm{MgO}$. Kane glasses show a trend of decreasing $\mathrm{CaO}$ beginning at about $8 \mathrm{wt} \% \mathrm{MgO}$. The boundary-layer fractionation trend shows the results of modeling a process of $50 \%$ crystallization of liquids in a boundary layer at the magma-cumulate interface, with the evolved liquid produced repeatedly mixed back into the main magma body. This model could explain the $\mathrm{MgO}-\mathrm{CaO}$ systematics in these glasses, however, it does not predict the formation of early, magnesian clinopyroxene. We are not suggesting that $\mathrm{Mg} \#$ in clinopyroxene and Fo in olivine are out of equilibrium, but that the

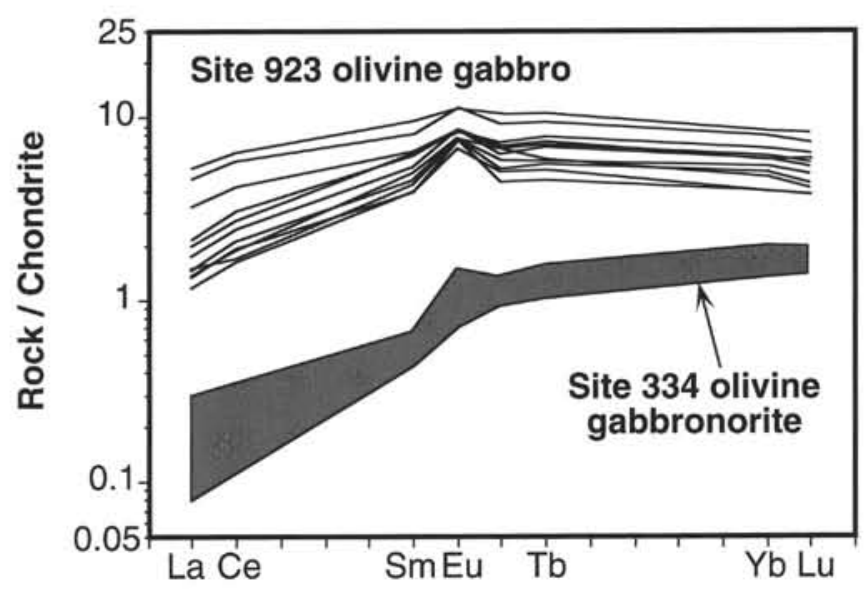

Figure 13. REEs in Leg 153 olivine gabbros and Site 334 olivine gabbronorite cumulates. Despite the complexities of cumulate rock crystallization, these rocks record differences in parental magma compositions.

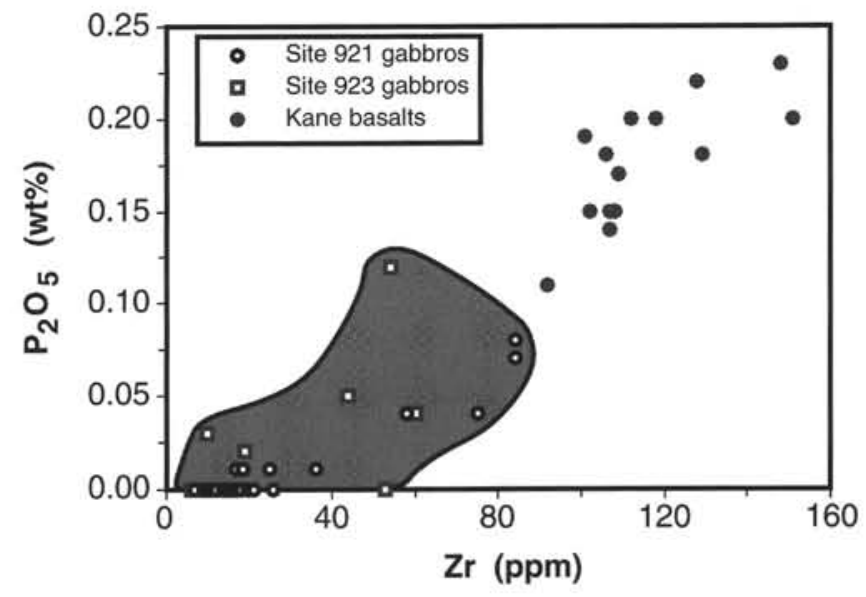

Figure 14. $\mathrm{Zr}$ vs. $\mathrm{P}_{2} \mathrm{O}_{5}$ in gabbroic whole rocks from Leg 153 and in Kane lavas. Leg $153 \mathrm{Zr}$ and $\mathrm{P}_{2} \mathrm{O}_{5}$ data are from shipboard XRF data (Cannat, Karson, Miller, et al., 1995).

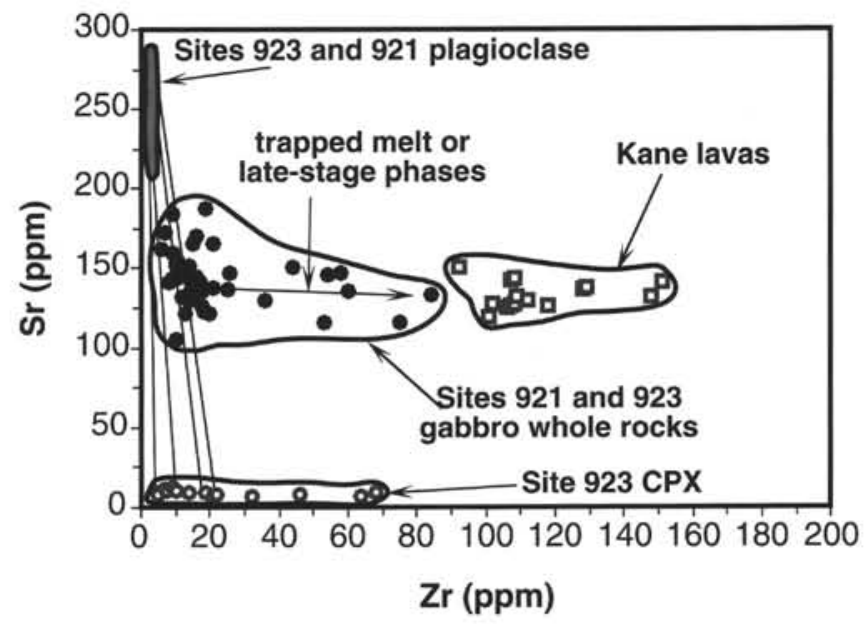

Figure $15 . \mathrm{Zr}$ vs. Sr in Leg 153 gabbroic rocks, Kane lavas, and minerals in gabbroic rocks. Cumulate rocks should fall to the left of tie lines connecting clinopyroxene (CPX) and plagioclase (olivine is very near zero in $\mathrm{Zr}$ and $\mathrm{Sr}$ contents). Clinopyroxene with enriched rims extends the clinopyroxene compositions to high $\mathrm{Zr}$ values. Further discussion is in the text. 


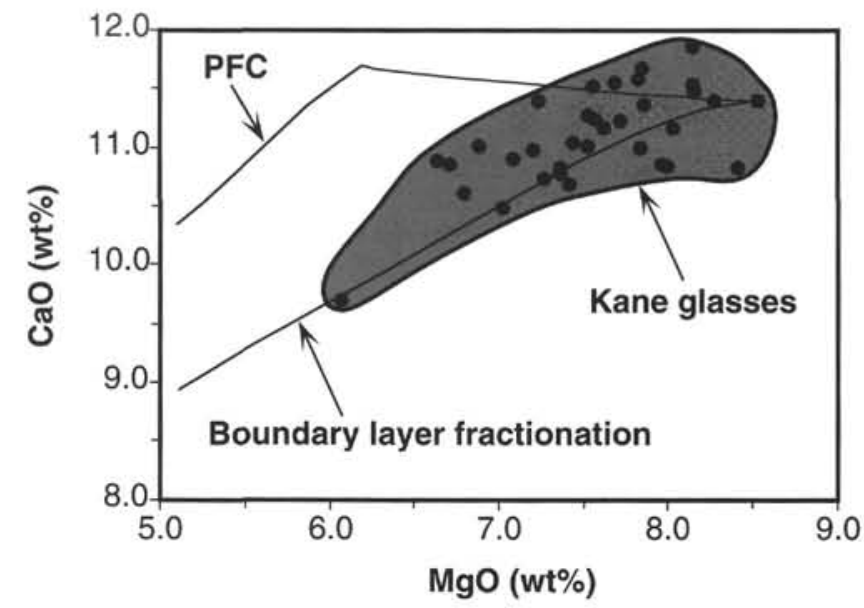

Figure 16. $\mathrm{MgO}$ vs. $\mathrm{CaO}$ in Kane glasses (data from Bryan et al., 1993). The trend labeled PFC is perfect fractional crystallization model calculated using the program of Nielsen (1988). Boundary-layer fractionation model was calculated using the program "In Situ" of Nielsen and DeLong (1992). $\mathrm{CaO}$ in Kane lavas decreases as $\mathrm{MgO}$ decreases at an earlier stage of fractionation than predicted based on crystallization experiments using Kane basalts (Tormey et al., 1987; Grove et al., 1990, 1992).

earliest formed clinopyroxene is more magnesian than should crystallize from Kane melts at low pressure.

One potential problem with the suggestion that these rocks crystallized at moderate pressure is the observation that the samples that have the highest $\mathrm{Mg} \#$ in clinopyroxene also have trace-element abundances that show that their parental liquids were more depleted in incompatible trace elements than Kane erupted basalts. The suggestion that $\mathrm{Mg} \#$ in clinopyroxene is too high for low-pressure fractionation is based on crystallization modeling of Kane basalts. The limited inferences that we can make about the major-element contents $\left(\mathrm{Na}_{2} \mathrm{O}\right.$ and $\mathrm{TiO}_{2}$; see Table 12) of the parental liquids of depleted series rocks suggest that their major-element compositions were similar to the main series parent magma. Despite the marked difference in incompatible trace-element contents of the two magma series, there is no evidence that there were large differences in major elements, and it is the major elements that determine when clinopyroxene begins to crystallize. Figures 1 through 6 show that minerals in rocks formed from the two magma series lie on the same trend in major- and minorelement compositions, suggesting that there were insignificant differences in the major-element compositions of their parental magmas. This observation suggests that it is appropriate to use modeling of erupted Kane basalts to make inferences about crystallization of the depleted series gabbros. Among all published 1-atm experiments on MORB liquids, the only experiments that produced clinopyroxene more magnesian than $\mathrm{Mg} \#$ of 84 involved an unusual large-ion-lithophile-enriched composition, or compositions that were doped with magnesian diopside (Grove and Bryan, 1983).

Crystallization at elevated pressure could also account for the $\mathrm{MgO}-\mathrm{CaO}$ trend defined by the Kane glasses (for examples of the effects of changing pressure on liquid lines of descent in $\mathrm{MgO}-\mathrm{CaO}$ plots, see Langmuir et al., 1992; and Elthon, 1993). Figure 17 (after Grove et al., 1992) shows the position of Kane aphyric rocks (data from Bryan et al., 1981) on the clinopyroxene-olivine-quartz pseudoternary phase diagram, with the location of clinopyroxene-olivine-plagioclase saturated boundaries at $1 \mathrm{~atm}, 2 \mathrm{kbar}$, and $8 \mathrm{kbar}$. Kane glasses are saturated in clinopyroxene at 2 to $5 \mathrm{kbar}$, but not at low pressure. So, both the erupted lavas and gabbroic rocks recovered from the MARK area are not consistent with simple low-pressure crystal fractionation, and an alternative model that could explain the glass trend (in situ crystallization, Langmuir 1989; also boundary-

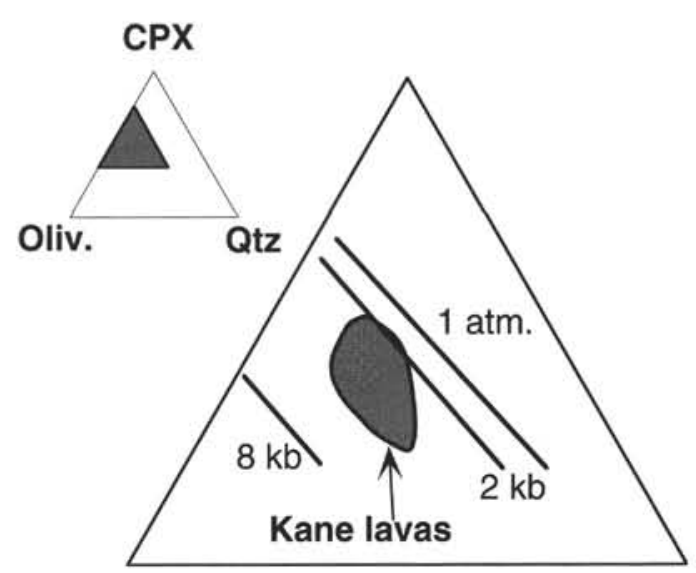

Figure 17. Clinopyroxene-olivine-quartz (CPX-Oliv.-Qtz) pseudoternary phase diagram showing the locations of clinopyroxene-olivine-plagioclase cosaturation boundaries at $1 \mathrm{~atm}, 2$, and $8 \mathrm{kbar}$, based on studies by Tormey et al. (1987) and Grove et al. (1990, 1992). Compositions of Kane lavas are consistent with moderate-pressure crystallization at 2-4 kbar.

layer fractionation, Nielsen and Delong, 1992) does not account for the magnesian clinopyroxene compositions in the gabbroic rocks. Figures $18 \mathrm{~A}$ and $18 \mathrm{~B}$ show Kane glasses and Leg 153 gabbroic rocks in $\mathrm{Mg} \#$ vs. $\mathrm{CaO}$, and $\mathrm{MgO}$ vs. $\mathrm{CaO}$, respectively. $\mathrm{Mg} \#$ in Kane glasses was calculated assuming that $\mathrm{Fe}^{2+} /$ total iron $=0.93$. $\mathrm{Mg} \#$ in gabbro was calculated with all iron as $\mathrm{FeO}$ (the conclusion that many of these rocks are sufficiently $\mathrm{Ca}$ and $\mathrm{Mg}$ rich to lead to early decline of $\mathrm{CaO}$ in the Kane basalts is unaffected by the proportion of iron in the ferric state in gabbroic rocks). On these plots, magnesian, high-CaO gabbroic cumulates have compositions that are appropriate to produce the observed trend in the glasses.

High $\mathrm{Mg}$ \# clinopyroxenes are a common feature in gabbroic cumulates from the ocean basins. Mid-Cayman Rise gabbroic rocks (Elthon, 1987), Leg 118 gabbros (Hébert et al., 1991), Site 334 rocks (Hodges and Papike, 1976; Ross and Elthon, 1993), and the suite that is the subject of the present study all contain high $\mathrm{Mg \#} \mathrm{clinopyroxene}$ that would not crystallize from erupted mid-ocean ridge basalts at low pressure. In some cases, the production of magnesian clinopyroxene and orthopyroxene is the result of crystallization of liquids unlike erupted MORBs in major-element composition (Site 334; Ross and Elthon, 1993), but in samples from Leg 153, the evidence for the involvement of such unusual melts is not observed. The production of high $\mathrm{Mg} \#$ clinopyroxene in these gabbroic rocks is a fundamental problem in understanding the evolution of MORBs. The necessity of early clinopyroxene crystallization to produce the observed compositions of MORBs has long been recognized (Bender et al., 1978; Bence et al., 1979). The evolution of basaltic rocks from the MidCayman Rise also requires early clinopyroxene crystallization (Elthon et al., 1995). Models for the widespread production of high $\mathrm{Mg \#}$ clinopyroxene from MORB require either moderate- to high-pressure crystallization or formation from melts unlike erupted MORB.

Observations of the Leg 153 gabbros that are difficult to reconcile with high-pressure crystallization are the fact that, in all rocks with high- $\mathrm{Mg} \#$ clinopyroxene, the poikilitic texture of clinopyroxene is suggestive of postcumulus crystallization, and the fact that these gabbros have not undergone pervasive plastic deformation. If these rocks crystallized at high pressure and clinopyroxene crystallized early, then one might expect that clinopyroxene should have a cumulus texture rather than being poikilitic. Also, if these rocks formed at 2-5 kbar, the depth of formation would be placed at least at the base of the oceanic crust, and up to about $8 \mathrm{~km}$ below the base of the crust. It is difficult to envision how such deeply formed rocks could be transported, en masse, into the crust and up to the seafloor without under- 

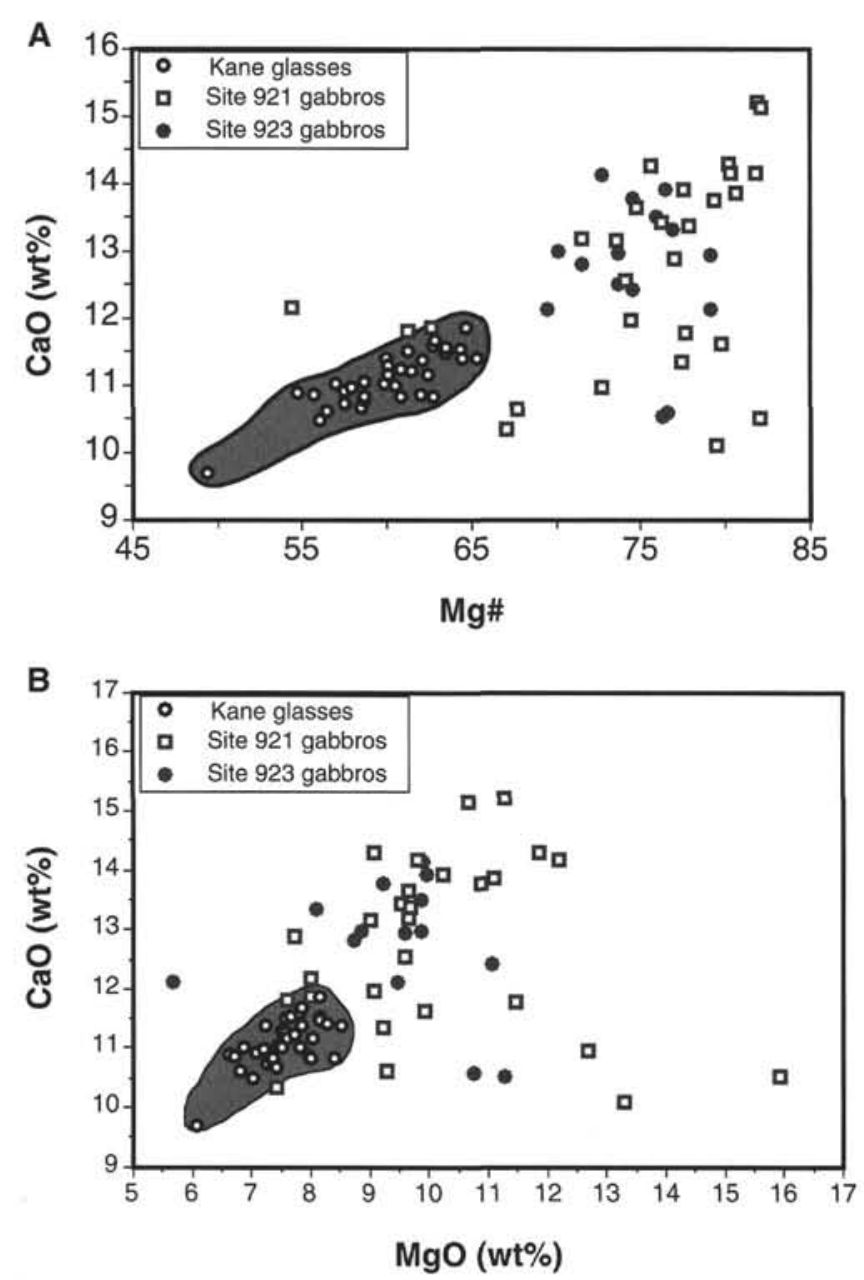

Figure 18. A. Mg\# vs. $\mathrm{CaO}$ in Kane lavas and gabbroic cumulates. Early crystallization of magnesian, high-Ca cumulates drives melt $\mathrm{CaO}$ down at early stages of fractional crystallization. $\mathbf{B} . \mathrm{MgO}$ vs. $\mathrm{CaO}$ in Kane lavas and Leg 153 gabbroic cumulates.

going pervasive plastic deformation. Discrete zones of high-temperature plastic deformation do, however, occur within the sections at Sites 923 and 921 .

The gabbros drilled at Site 923 crystallized from two parental magmas that are not related to one another by fractional crystallization. Presumably, these two parental magmas formed by varying degrees of fractional melting of the suboceanic mantle, as envisioned in recent models of MORB petrogenesis (Johnson et al., 1990). The main series magmas are derivatives of relatively low-degree melts, whereas the depleted series magmas were formed by higher-degree melting. The preservation of geochemical signatures related to the different parental magmas that formed this suite shows that varyingdegree fractional melts are not homogenized before delivery to the site of gabbro formation.

\section{CONCLUSIONS}

Cumulate gabbroic rocks drilled during Leg 153 record the crystal fractionation of magmas. Bulk-rock incompatible trace-element abundances and major-element mineral compositions clearly show that these rocks are cumulates. Modeling of bulk-rock incompatible trace elements suggests that the rocks include from about $1 \%$ to $30 \%$ trapped melt. Evidence for variability in parental melt trace-element compositions is revealed by trace-element compositions of clinopyroxenes. Some bulk-mineral separates are enriched in trace elements because of the growth of enriched rims or zones, so that estimates of magma compositions derived from these mineral separates are upper limits on magma compositions. More accurate estimates are derived by using the more depleted compositions determined by ion probe, as these are unaffected or less affected by postcumulus enrichment processes. It appears that many of the gabbroic rocks studied here crystallized from melts geochemically similar to erupted Kane lavas, although some samples crystallized from melts more depleted in incompatible trace elements. $\mathrm{Mg \#}$ of clinopyroxene in some samples are higher than would form from Kane melts at low pressure, or than would form in boundary-layer fractionation models. Moderate-pressure crystallization at $2-5$ kbar could account for the formation of these magnesian clinopyroxene grains, although we cannot rule out the involvement of melts unlike any erupted MORBs that could have crystallized magnesian clinopyroxene at low pressure.

\section{ACKNOWLEDGMENTS}

Access to the INAA laboratory at Johnson Space Center was provided by Dr. M. Lindstrom and assistance in data reduction was provided Dr. D. Mittlefehldt. Assistance in sample preparation and collection of gamma-ray spectra was provided by Dr. D. Mittlefehldt and Rene Martinez. Access to the ion probe laboratory and assistance in the use of the instrument was provided by Dr. N. Shimizu. Support for this project was provided by the Joint Oceanographic Institutions. Excellent efforts by the ships crew and drilling team on the JOIDES Resolution and by ODP technical support staff made this work possible.

\section{REFERENCES}

Anders, E., and Ebihara, M., 1982. Solar-system abundances of the elements. Geochim. Cosmochim. Acta., 46:2363-2380.

Batiza, R., and Vanko, D.A., 1985. Petrologic evolution of large failed rifts in the eastern Pacific: petrology of volcanic and plutonic rocks from the Mathematician Ridge area and the Guadalupe Trough. J. Petrol., 26:564602.

Bence, A.E., Baylis, D.M., Bender, J.F., and Grove, T.L., 1979. Controls on the major and minor element chemistry of mid-ocean ridge basalts and glasses. In Talwani, M., Harrison, C.G., and Hayes D.E. (Eds.), Deep Sea Drilling Results in the Atlantic Ocean: Ocean Crust. Maurice Ewing Ser., Am. Geophys. Union, 2:331-341.

Bender, J.F., Hodges, F.N., and Bence, A.E., 1978. Petrogenesis of basalts from the Project FAMOUS area: experimental study from 0 to $15 \mathrm{kbar}$. Earth Planet. Sci. Lett., 41:277-302.

Bryan, W.B., Humphris, S.E., Thompson, G., and Casey, J.F., 1993. Comparative volcanology of small axial eruptive centers in the MARK area. $J$. Geophys. Res., 99:2973-2984.

Bryan, W.B., Thompson, G., and Ludden, J.N., 1981. Compositional variation in normal MORB from $22^{\circ}-25^{\circ} \mathrm{N}$ : Mid-Atlantic Ridge and Kane Fracture Zone. J. Geophys. Res., 86:11815-11836.

Cannat, M., Karson, J.A., Miller, D.J., et al., 1995. Proc. ODP, Init. Repts., 153: College Station, TX (Ocean Drilling Program).

Elthon, D., 1987. Petrology of gabbroic rocks from the Mid-Cayman Rise spreading center. J. Geophys. Res., 92:658-682.

- 1993. Crystallization of mid-ocean ridge basalts at moderate to high pressures. Eur. J. Mineral., 5:1025-1037.

Elthon, D., Ross, D.K., and Meen, J.K., 1995. Compositional variations of basaltic glasses from the Mid-Cayman Rise spreading center. J. Geophys. Res., 100:12497-12512.

Grove, T.L., and Bryan, W.B., 1983. Fractionation of pyroxene-phyric MORB at low pressure: an experimental study. Contrib. Mineral. Petrol., 84:293-309.

Grove, T.L., Kinzler, R.J., and Bryan, W.B., 1990. Natural and experimental phase relations of lavas from Serocki volcano. In Detrick, R., Honnorez, J., Bryan, W.B., Juteau, T., et al., Proc. ODP, Sci. Results, 106/109: College Station, TX (Ocean Drilling Program), 9-17. 
1992. Fractionation of mid-ocean ridge basalt (MORB). In Morgan, J.P., Blackman, D.K., and Sinton, J.M. (Eds.), Mantle Flow and Melt Generation at Mid-Ocean Ridges. Geophys. Monogr., Am. Geophys. Union, 71:281-310.

Grutzeck, M., Kridelbaugh, S., and Weill, D., 1974. The distribution of Sr and REE between diopside and silicate liquid. Geophys. Res. Lett., $1: 273-275$.

Haggerty, S.E., 1987. Metasomatic mineral titanates in upper mantle xenoliths. In Nixon, P.H. (Ed.), Mantle Xenoliths: Chichester (Wiley and Sons), 671-690.

Hart, S.R., and Dunn, T., 1993. Experimental clinopyroxene/melt partitioning of 24 trace elements. Contrib. Mineral. Petrol., 113:1-8.

Haskin, L.A., and Salpas, P.A., 1992. Genesis of compositional characteristics of Stillwater AN-I and AN-II thick anorthosite units. Geochim. Cosmochim. Acta, 56:1187-1212.

Hébert, R., Constantin, M., and Robinson, P.T., 1991. Primary mineralogy of Leg 118 gabbroic rocks and their place in the spectrum of oceanic mafic igneous rocks. In Von Herzen, R.P., Robinson, P.T., et al., Proc. ODP, Sci. Results, 118: College Station, TX (Ocean Drilling Program), 3-20.

Hodges, F.N., and Papike, J.J., 1976. DSDP Site 334: magmatic cumulates from oceanic layer 3.J. Geophys. Res., 81:4135-4151.

Irvine, T.N., 1982. Terminology for layered intrusions. J. Petrol., 23:127162.

Johnson, K.T.M., Dick, H.J.B., and Shimizu, N., 1990. Melting in the oceanic upper mantle: an ion microprobe study of diopsides in abyssal peridotites. J. Geophys. Res., 95:2661-2678.

Keil, K., and Fricker, P.E., 1974. Baddeleyite $\left(\mathrm{ZrO}_{2}\right)$ in gabbroic rocks from Axel Heiberg Island, Canadian Arctic Archipelago. Am. Mineral., 59:249-253.

Langmuir, C.H., 1989. Geochemical consequences of in situ crystallization. Nature, 340:199-205.

Langmuir, C.H., Klein, E., and Plank, T., 1992. Petrological systematics of mid-ocean ridge basalts: constraints on melt generation beneath ocean ridges. In Morgan, J., Blackman, D., Sinton, J. (Eds.), Mantle Flow and Melt Generation at Mid-Ocean Ridges. Geophys. Monogr., Am. Geophys. Union, 7:183-277.

Lindstrom, D.J., and Korotev, R.L., 1982. TEABAGS: computer programs for instrumental neutron activation analysis. J. Radioanal. Chem., 70:439-458.

Meyer, P.S., Dick, H.J.B., and Thompson, G., 1989. Cumulate gabbros from the Southwest Indian Ridge, $54^{\circ} \mathrm{S}-7^{\circ} 16^{\prime} \mathrm{E}$ : implications for magmatic processes at a slow spreading ridge. Contrib. Mineral. Petrol., 103:4463.

Nagasawa, H., 1970. Rare earth element concentrations in zircons and apatites and their host dacites and granites. Earth Planet. Sci. Lett., 9:359364.

Nielsen, R.L., 1988. A model for the simulation of combined major and trace element liquid lines of descent. Geochim. Cosmochim. Acta, 52:27-38.

Nielsen, R.L., and Delong, S.E., 1992. A numerical approach to boundary layer fractionation: application to differentiation in natural magma systems. Contrib. Mineral. Petrol., 110:355-369.

Ross, D.K., 1994. Geochemistry of cumulate rocks from the Stillwater layered intrusion and the Mid-Atlantic Ridge: magma evolution recorded by cumulus mineral compositions [Ph.D. dissert.]. Univ. of Houston, Houston, TX.

Ross, K., and Elthon, D., 1993. Cumulates from strongly depleted midocean-ridge basalt. Nature, 365:826-829.

, 1994. Baddeleyite $\left(\mathrm{ZrO}_{2}\right)$ in a gabbroic cumulate from the MidAtlantic Ridge near the Kane Fracture Zone. Eos, 75:627.

Scatena-Wachel, D.E., and Jones, A.P., 1984. Primary baddeleyite $\left(\mathrm{ZrO}_{2}\right)$ in kimberlite from Benfontein, South Africa. Mineral. Mag., 48:257-261.

Shimizu, N.S., and Hart, S.R., 1982. Applications of the ion microprobe to geochemistry and cosmochemistry. Ann. Rev. Earth Planet. Sci., 10:483526.

Smith, D.K., and Newkirk, H.W., 1965. The crystal structure of baddeleyite (monoclinic $\mathrm{ZrO}_{2}$ ) and its relation to the polymorphism of $\mathrm{ZrO}_{2}$. Acta Crystallogr., 18:983-991.

Tormey, D.R., Grove, T.L., and Bryan, W.B., 1987. Experimental petrology of normal MORB near the Kane Fracture Zone: $22^{\circ}-25^{\circ} \mathrm{N}$, Mid-Atlantic Ridge. Contrib. Mineral. Petrol., 96:121-139.

Wager, L.R., Brown, G.M., and Wadsworth, W.J., 1960. Types of igneous cumulates. J. Petrol., 1:73-85.

Williams, C.T., 1978. Uranium-enriched minerals in mesostasis areas of the Rhum layered pluton. Contrib. Mineral. Petrol., 66:29-39.

\author{
Date of initial receipt: 31 July 1995 \\ Date of acceptance: 13 May 1996 \\ Ms 153SR-023
}

